Atmos. Chem. Phys., 13, 3363-3378, 2013

www.atmos-chem-phys.net/13/3363/2013/

doi:10.5194/acp-13-3363-2013

(C) Author(s) 2013. CC Attribution 3.0 License.

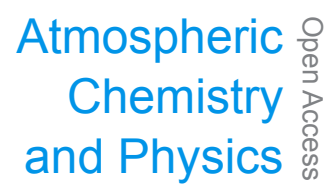

(c) (i)

\title{
Iodine monoxide in the Western Pacific marine boundary layer
}

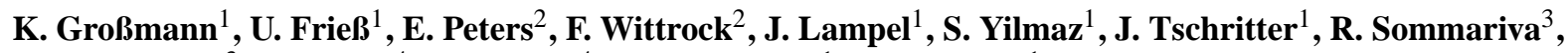 \\ R. von Glasow ${ }^{3}$, B. Quack ${ }^{4}$, K. Krüger ${ }^{4}$, K. Pfeilsticker ${ }^{1}$, and U. Platt ${ }^{1}$ \\ ${ }^{1}$ Institute of Environmental Physics, University of Heidelberg, Heidelberg, Germany \\ ${ }^{2}$ Institute of Environmental Physics, University of Bremen, Bremen, Germany \\ ${ }^{3}$ School of Environmental Sciences, University of East Anglia, Norwich, UK \\ ${ }^{4}$ GEOMAR, Helmholtz Centre for Ocean Research Kiel, Kiel, Germany \\ Correspondence to: K. Großmann (katja.grossmann@iup.uni-heidelberg.de)
}

Received: 24 September 2012 - Published in Atmos. Chem. Phys. Discuss.: 19 October 2012

Revised: 22 January 2013 - Accepted: 4 March 2013 - Published: 25 March 2013

\begin{abstract}
A latitudinal cross-section and vertical profiles of iodine monoxide (IO) are reported from the marine boundary layer of the Western Pacific. The measurements were taken using Multi-Axis Differential Optical Absorption Spectroscopy (MAX-DOAS) during the TransBrom cruise of the German research vessel Sonne, which led from Tomakomai, Japan $\left(42^{\circ} \mathrm{N}, 141^{\circ} \mathrm{E}\right)$ through the Western Pacific to Townsville, Australia $\left(19^{\circ} \mathrm{S}, 146^{\circ} \mathrm{E}\right)$ in October 2009. In the marine boundary layer within the tropics (between $20^{\circ} \mathrm{N}$ and $5^{\circ} \mathrm{S}$ ), IO mixing ratios ranged between 1 and $2.2 \mathrm{ppt}$, whereas in the subtropics and at mid-latitudes typical IO mixing ratios were around $1 \mathrm{ppt}$ in the daytime. The profile retrieval reveals that the bulk of the IO was located in the lower part of the marine boundary layer. Photochemical simulations indicate that the organic iodine precursors observed during the cruise $\left(\mathrm{CH}_{3} \mathrm{I}, \mathrm{CH}_{2} \mathrm{I}_{2}, \mathrm{CH}_{2} \mathrm{ClI}, \mathrm{CH}_{2} \mathrm{BrI}\right)$ are not sufficient to explain the measured IO mixing ratios. Reasonable agreement between measured and modelled IO can only be achieved if an additional sea-air flux of inorganic iodine (e.g., $\mathrm{I}_{2}$ ) is assumed in the model. Our observations add further evidence to previous studies that reactive iodine is an important oxidant in the marine boundary layer.
\end{abstract}

\section{Introduction}

Past studies indicated that inorganic iodine may exert considerable influence on the oxidation capacity and particle formation of the marine atmosphere (e.g., Chameides and Davis, 1980; Solomon et al., 1994; Platt and Hönninger, 2003; SaizLopez et al., 2012). Unequivocal evidence for the presence of reactive iodine species and the important role they play in various atmospheric processes have been provided through a suite of ground, ship and satellite-based observations of reactive iodine species $\left(\mathrm{I}_{2}, \mathrm{IO}\right.$ and OIO) (e.g. Read et al., 2008; Schönhardt et al., 2008; Seitz et al., 2010; Mahajan et al., $2010 \mathrm{~b}$ ) as well as of iodine tied to aerosols (e.g. Burkholder et al., 2004; Hayase et al., 2010; McFiggans et al., 2010) along with supporting modelling studies (e.g., von Glasow et al., 2002; Saiz-Lopez et al., 2006, 2012; Sommariva et al., 2012, and references therein).

Past observational studies on atmospheric iodine already covered many areas of the globe, including both polar regions, coastal regions, islands at mid- and low-latitudes and salt lakes (e.g. Saiz-Lopez et al., 2012, and references therein).

Nevertheless, information regarding reactive iodine in the air over the open ocean remained sparse mainly due to a lack of shipborne observations. Table 1 provides an overview of the recent ground-based observations of IO in the troposphere over open ocean, using the DOAS technique. Landbased IO measurements with a strong connection to the ocean have been conducted on several islands. For example at Tenerife, IO mixing ratios up to $3 \mathrm{ppt}$ were observed (Allan et al., 2000), or on the Maldives IO mixing ratios ranging between 2.4 and $3.1 \mathrm{ppt}$ were inferred for assumed boundary layer heights of $1 \mathrm{~km}$ and $350 \mathrm{~m}$, respectively (Oetjen, 2009). In addition, on the Cape Verde Islands IO mixing ratios ranging between 1 and 3 ppt were observed with a solar radiation driven diurnal cycle (Read et al., 2008; Mahajan et al., 2010a). Furthermore, in a recent study a latitudinal cross-section of IO was inferred by Mahajan et al. (2012) 
Table 1. Past open ocean ground-based observations of IO in the troposphere using the active and passive DOAS technique.

\begin{tabular}{|c|c|c|c|c|c|}
\hline Region & Location & Instrument & $\begin{array}{l}\text { Max. Mix. } \\
\text { Ratio [ppt] }\end{array}$ & $\begin{array}{l}\text { Error } \\
\pm(2 \sigma) \\
{[\mathrm{ppt}]}\end{array}$ & Reference \\
\hline \multirow[t]{5}{*}{ land-based } & Tenerife, Spain (1997) & LP-DOAS & 3 & 0.3 & Allan et al. (2000) \\
\hline & $\begin{array}{l}\text { Tenerife, Spain, free } \\
\text { troposphere }(2010)\end{array}$ & MAX-DOAS & 0.4 & 0.2 & Puentedura et al. (2012) \\
\hline & Cape Verde (2006-2007) & LP-DOAS & 3.1 & 0.4 & Mahajan et al. (2010a) \\
\hline & Cape Verde (2010) & MAX-DOAS & 1.5 & 0.6 & Carpenter et al. (2010) \\
\hline & Maledive Islands (1999) & MAX-DOAS & 2.8 & 0.7 & Oetjen (2009) \\
\hline \multirow[t]{2}{*}{ ship-borne } & Eastern Pacific (2010) & MAX-DOAS & $0.9^{1}$ & - & Mahajan et al. (2012) \\
\hline & Western Pacific (2009) & MAX-DOAS & $2.2\left(1.5^{1}\right)$ & $0.5\left(0.9^{2}\right)$ & this study \\
\hline
\end{tabular}

${ }^{1}$ Maximum daily mean; ${ }^{2}$ daily mean.

with maximum IO mixing ratios reaching $1.2 \mathrm{ppt}$ in regions of low biological activity, i.e., in the latitude bands $5^{\circ} \mathrm{N}$ to $20^{\circ} \mathrm{N}$ and $20^{\circ} \mathrm{S}$ to $40^{\circ} \mathrm{S}$ at around $80^{\circ} \mathrm{W}$ to $130^{\circ} \mathrm{W}$ in the Eastern Pacific.

Using the SCIAMACHY satellite instrument, IO was also detected from space, mostly over high southern latitudes and over some biological hot-spot regions (e.g., the African and South American west coasts), where upwelling of nutrient rich waters and tentatively large emissions of iodocarbons occur (Saiz-Lopez et al., 2007; Schönhardt et al., 2008, 2012). However, satellite-based IO remote sensing is limited by the relatively low detection sensitivity, in particular, over surfaces with low reflectivity, such as the tropical oceans, where the presence of IO can be suspected. Therefore, more IO measurements covering wider and yet unexplored oceans, such as the Pacific, are highly desirable, in order to determine the importance of reactive iodine for the photochemistry and its potential for aerosol formation in the marine boundary layer (MBL) on a global scale.

Information regarding the vertical distribution of IO is also sparse; the only published IO vertical profiles were inferred from MAX-DOAS measurements at Izaña, Canary Islands (Puentedura et al., 2012). In fact, these measurements not only revealed the presence of sizable amounts of IO within the marine boundary layer, but also indicated small amounts in the overlaying free troposphere.

The present paper reports on shipborne MAX-DOAS measurements in the Western Pacific from which a latitudinal cross-section and vertical profiles of IO are inferred. These IO measurements are complemented by sea-to-air flux measurements of the organic iodine precursor gases methyl iodide $\left(\mathrm{CH}_{3} \mathrm{I}\right)$, chloroiodomethane $\left(\mathrm{CH}_{2} \mathrm{ClI}\right)$, bromoiodomethane $\left(\mathrm{CH}_{2} \mathrm{BrI}\right)$ and diiodomethane $\left(\mathrm{CH}_{2} \mathrm{I}_{2}\right)$ and the results of a photochemical model which aim to close the budget of organic and inorganic iodine source strengths, the atmospheric IO abundance and the strength of potential sink processes. It is argued that by adjusting the source strength of the iodocarbons and inorganic iodine, the marine surface air may sustain the detected abundance and vertical profile of IO.

The paper is organised as follows: Sect. 2 gives an overview of the TransBrom Sonne cruise in the Western Pacific. In Sect. 3, the major tools and methods of the study are described. Section 4 reports on the results with respect to the observed and inferred source strengths of organic iodine precursors, the photochemistry of inorganic iodine and possible correlations with observed IO. Section 5 compares the measurements to model calculations and Sect. 6 concludes the study.

\section{The TransBrom Sonne cruise during October 2009}

The TransBrom expedition was conducted aboard the German research vessel (R/V) Sonne departing in Tomakomai, Japan $\left(42^{\circ} \mathrm{N}, 141^{\circ} \mathrm{E}\right)$ on 9 October 2009 and arriving at Townsville, Australia $\left(19^{\circ} \mathrm{S}, 146^{\circ} \mathrm{E}\right)$ on 24 October 2009 (cruise length of $7500 \mathrm{~km}$ ). An overview of the meteorology during the cruise is given by Krüger and Quack (2012). Here the viewing conditions are added. At the beginning of the cruise, the weather was influenced by the typhoon Melor which had weakened to an extratropical storm when reaching the R/V Sonne causing heavy rain and strong winds in the harbour of Tomakomai on 9 October 2009. On 10 October 2009, the weather was characterised by almost clear skies providing a good visibility, but on 11 and 12 October 2009 the cloud coverage increased. During the night of 13 October 2009, the next tropical depression (Nepartak) hit the R/V Sonne causing the largest winds recorded during the whole cruise and heavy rain until noon. On 14 October 2009 clear skies provided the best viewing condition during the whole cruise. In the afternoon of 15 October 2009, the R/V Sonne encountered again high wind speeds due to the tropical depression Lupit passing by. The days from 15 to 22 October 2009 were partly cloudy, and atmospheric instability initiated large convective cells which on occasions led to precipitation 
during the afternoons. The weather on the final days of the cruise was again rather sunny with infrequent occurrence of clouds.

In order to facilitate the discussion later in the paper, the whole cruise track is divided into three parts, part 1 ranging from Tomakomai, Japan $\left(42^{\circ} \mathrm{N}, 141^{\circ} \mathrm{E}\right)$ to $\left(20^{\circ} \mathrm{N}\right.$, $\left.146^{\circ} \mathrm{W}\right)(9-14$ October 2009$)$, part 2 from $\left(20^{\circ} \mathrm{N}, 146^{\circ} \mathrm{W}\right)$ to $\left(8^{\circ} \mathrm{S}, 154^{\circ} \mathrm{W}\right)(14-21$ October 2009$)$ and part 3 part from $\left(8^{\circ} \mathrm{S}, 154^{\circ} \mathrm{W}\right)$ to Townsville $\left(19^{\circ} \mathrm{S}, 146^{\circ} \mathrm{E}\right)(21-24$ October 2009).

Major objectives of the TransBrom Sonne cruise were the investigation of the halocarbon concentrations in the surface seawater and air, and the estimation of their seaair source strengths and sinks. This appears to be relevant since the Western Pacific is regarded as the main "entrance gate" for naturally emitted halocarbons entering the stratosphere (Bonazzola and Haynes, 2004; Krüger et al., 2008; Fueglistaler et al., 2009). Further, Fourier Transform infrared spectrometry (FTIR) measurements of $\mathrm{CO}$ and $\mathrm{O}_{3}$ (Ridder et al., 2012) as well as satellite and in-situ measurements of phytoplankton complemented our measurements. Finally, our trace gas studies were complemented by meteorological measurements and the release of radio- and ozonesondes (Krüger and Quack, 2012).

Two MAX-DOAS instruments were operated next to each other aboard the R/V Sonne with the same line-of-sight. The IUP Bremen group focussed on the measurements of $\mathrm{NO}_{2}$ and $\mathrm{HCHO}$ and their validation with satellite measurements (Peters et al., 2012) and the IUP Heidelberg group focussed on the retrieval of IO mixing ratios and profiles in the MBL along the cruise track (this study).

\section{Methods}

While IO was measured using the MAX-DOAS method, air samples were taken simultaneously, although at a lower frequency, for the analysis of some major iodocarbon species $\left(\mathrm{CH}_{3} \mathrm{I}, \mathrm{CH}_{2} \mathrm{I}_{2}, \mathrm{CH}_{2} \mathrm{ClI}, \mathrm{CH}_{2} \mathrm{BrI}\right)$ from which sea-air fluxes were inferred. Since the measured IO mixing ratios were also compared to simulations of the one-dimensional photochemical model MISTRA v7.4.1 (von Glasow et al., 2002; Sommariva et al., 2012), some details of the MISTRA simulations are provided below.

\subsection{The (MAX-)DOAS measurement principle}

For the retrieval of IO, the method of Differential Optical Absorption Spectroscopy (DOAS) was applied (Platt and Stutz, 2008). This method is a remote sensing technique using scattered sunlight that is attenuated along its light path in the atmosphere according to the Lambert-Beer law. It relies on the fact that the optical density can be separated in a narrow (differential) band component accounting for the absorption processes of the different trace gas molecules and a broad band component describing the scattering effects.

In the Multi-Axis DOAS (MAX-DOAS) technique (Hönninger et al., 2004; Wittrock et al., 2004), spectra of scattered sunlight are recorded under different elevation angles $\alpha$ between the zenith and the horizon. Low elevation angle measurements have a higher sensitivity to lower tropospheric layers and, thus, the MAX-DOAS method has an increased sensitivity towards tropospheric absorbers located near the surface.

The MAX-DOAS measurements yield differential slant column densities (dSCDs) $\Delta S$ for each fitted trace gas: $\Delta S(\alpha)=S(\alpha)-S_{\text {ref }}$ with $S(\alpha)$ being the slant column density (SCD) recorded at the elevation angle $\alpha$ and $S_{\text {ref }}$ being the SCD of the Fraunhofer reference spectrum usually measured towards the zenith $\left(\alpha=90^{\circ}\right)$. The SCD is defined as the concentration $c$ of a specific absorber integrated along the light path $L$ and is given in units of molec $\mathrm{cm}^{-2}$.

Using radiative transport models, the SCDs can be converted to vertical column densities (VCD) $V$ by simulating the air mass factor (AMF) $A$, which is the ratio of $S$ and $V$. $V$ is defined as the concentration $c$ integrated along the vertical height $z$ and is in turn independent of the length $L$ of the light path.

\subsection{The MAX-DOAS instrument}

The IUP Heidelberg MAX-DOAS instrument on the R/V Sonne consisted of the following major parts: a telescope unit, in which a plano-convex quartz lens collected the skylight into the approximately circular entrance area of a quartz fibre bundle with 37 individual optical fibres of $100 \mu \mathrm{m}$ core diameter forming a telescope field of view of $0.5^{\circ}$. At the fibre bundle exit, the single optical fibres of the bundle were arranged to a single column serving as the entrance slit of the Acton SpectraPro 300i Czerny-Turner optical spectrometer. The optical spectrometer was equipped with an Andor CCD detector camera (model DU 440-BU) with 2048 horizontal (i.e., in dispersion direction) and 512 vertical pixels. The optical spectrometer covered a wavelength range from $327 \mathrm{~nm}$ to $470 \mathrm{~nm}$, with a full width half maximum resolution of $0.5 \mathrm{~nm}$, or 7.2 detector pixels. A personal computer was used to control the instrument, to store the data and for online data analysis. The performance of the instrument was assessed during a recent intercomparison campaign (Roscoe et al., 2010).

The telescope was attached at the portside on top of the rail of the upper deck of the R/V Sonne, approximately $15 \mathrm{~m}$ above sea level. The viewing direction was oriented perpendicular to the heading of the ship. The rolling movement of the ship (rotation of the ship along the heading axis) was largely compensated for by employing an inclinometer, of which the output signal was used to continuously stabilise the elevation angle of the telescope during the measurements. The optical spectrometer was placed in the scientific bridge 
room of the R/V Sonne and kept at a temperature of $38^{\circ} \mathrm{C}$, in order to guarantee a stable optical imaging.

During the routine measurement mode, a set of 1000 scattered skylight spectra was added for each chosen elevation angle, $\alpha=90^{\circ}$ (zenith), $20^{\circ}, 10^{\circ}, 7^{\circ}, 5^{\circ}, 3^{\circ},-45^{\circ}$. One elevation angle sequence lasted for about seven minutes and the sequences were continuously repeated as long as the solar zentih angle (SZA) was lower than $85^{\circ}$. During twilight $\left(85^{\circ}<\mathrm{SZA}<97^{\circ}\right)$, only zenith measurements were performed, followed by detector dark current and offset measurements during nighttime.

\subsection{DOAS data analysis}

The scattered sunlight spectra measured by MAX-DOAS were analysed for the absorption of $\mathrm{IO}$ and $\mathrm{O}_{4}$ using the software WinDOAS provided by the IASB/BIRA (Belgian Institute for Space Aeronomy) (Van Roozendael and Fayt, 2001). The WinDOAS code was also used for the convolution of all absorption cross-sections reported in the literature, whereas the Ring spectrum was calculated using the software $D O A$ SIS (Kraus, 2006). In DOASIS the Ring spectrum was calculated according to Bussemer (1993) by dividing a Raman smoothed skylight spectrum with the original skylight spectrum (i.e., the Fraunhofer reference spectrum), both being wavelength normalised.

Since in the tropics at local noon, the measured zenith sky spectra were too bright leading to a saturation of the detector, instead local noon skylight spectra measured at an elevation angle of $\alpha=20^{\circ}$ were taken as Fraunhofer reference spectra.

Since during an individual elevation sequence the changes of the stratospheric slant column densities were small due to similar light paths in the stratosphere for all elevation angles, their contribution cancelled out for two adjacent $\alpha=20^{\circ}$ measurements and, thus, $\Delta S(\alpha)$ did not contain any stratospheric residual absorption. For the spectral retrieval, each $20^{\circ}$ elevation angle spectrum was allowed to be wavelengthshifted relative to the high resolution solar Fraunhofer spectrum of Kurucz et al. (1984). Thereby, changes in the wavelength calibration, for example, due to variations of the spectrometer temperature, were compensated for. For every $20^{\circ}$ Fraunhofer reference spectrum, a Ring spectrum was calculated and shifted the same way as the reference spectrum. The respective reference and Ring spectrum were then used to evaluate the measured skylight spectra recorded at the other elevation angles of the measurement sequence.

The IO analysis was performed in the wavelength interval ranging from 417.5 to $438.2 \mathrm{~nm}$, encompassing three vibrational IO absorption bands. The following absorption crosssections were included into the spectral retrieval: an IO spectrum from Spietz et al. (2005), an $\mathrm{NO}_{2}$ spectrum at $298 \mathrm{~K}$ from Vandaele et al. (1998), an $\mathrm{O}_{3}$ spectrum at $223 \mathrm{~K}$ from Bogumil et al. (2000), an $\mathrm{H}_{2} \mathrm{O}$ spectrum from Rothman et al. (2009) (HITRAN), and finally an atmospheric Ring spectrum calculated according to recommendations of Chance and Spurr (1997). The latter accounted for the filling-in of the solar Fraunhofer lines by rotational Raman scattering of air molecules. An absorption spectrum of glyoxal (Volkamer et al., 2005) was not included in the spectral retrieval, as glyoxal was not found in a spectral pre-analysis performed in the wavelength range from 450 to $461 \mathrm{~nm}$, encompassing the largest glyoxal absorption band. Furthermore, a multiplicative polynomial of 3rd order was included in order to account for the broadband spectral structures due to atmospheric Rayleigh and Mie scattering. Spectrometer straylight was accounted for by an additive polynomial of first order (i.e., assuming a linear wavelength dependence of the straylight). The whole package of reference spectra was allowed to be wavelength-shifted relative to the ratio of measured atmospheric spectra. All absorption cross-sections were convolved to the spectral resolution of the instrument using the mercury emission line located at $404.66 \mathrm{~nm}$.

In addition, spectral retrieval exercises indicated that inelastic Vibrational Raman Scattering (VRS) by oceanic water also needed to be considered. The VRS is known to be in particular relevant for measurements over oceanic water of low chlorophyll concentrations (Vountas et al., 2003; Dinter, 2005). Hence a VRS compensation spectrum (provided by T. Dinter, IUP Bremen, personal communication, 2011) was included in the spectral retrieval. A typical example for the retrieved IO absorption including the oceanic VRS is shown in Fig. 1a. The spectrum was recorded at $19.87^{\circ} \mathrm{N}$ and $147.15^{\circ} \mathrm{E}$ at an elevation angle of $3^{\circ}$ at $15: 13$ local time $\left(\mathrm{SZA}=55.79^{\circ}\right)$ on 14 October 2009. Spectral retrieval exercises including/excluding the VRS indicated that the inferred IO dSCD was $1.56 \times 10^{13} \mathrm{molec} \mathrm{cm}^{-2}$ versus $1.89 \times 10^{13} \mathrm{molec} \mathrm{cm}^{-2}$ and the residual root-mean-square (RMS) was $1.50 \times 10^{-4}$ versus $1.67 \times 10^{-4}$, respectively, i.e., the IO dSCD increased by about $20 \%$ while the residual increased by about $10 \%$, thus, providing evidence that the VRS compensation spectrum needed to be included in the spectral retrieval. Furthermore, modelling studies of the relative number of photons that are back-scattered from the ocean surface layer using the radiative transfer model McArtim (see Sect. 3.4.1) suggested that, for elevation angles smaller than $10^{\circ}$, a wavelength of $428 \mathrm{~nm}$, an SZA of $30^{\circ}$, a relative azimuth angle of $90^{\circ}$ and an oceanic albedo of 0.054 (Jin et al., 2002), $10-15 \%$ of the detected photons were back-scattered in the oceanic surface layer. Both findings led us to include a VRS compensation spectrum in the spectral retrieval.

The analysis of $\mathrm{O}_{4}$ was performed in the wavelength interval ranging from 348 to $369 \mathrm{~nm}$, where a single absorption band is located. The following absorption cross-sections were included into the spectral retrieval: $\mathrm{O}_{4}$ from Hermans et al. (1999), $\mathrm{BrO}$ at $298 \mathrm{~K}$ from Wilmouth et al. (1999), $\mathrm{HCHO}$ from Meller and Moortgat (2000), $\mathrm{NO}_{2}$ at $298 \mathrm{~K}, \mathrm{O}_{3}$ at $223 \mathrm{~K}$ and $243 \mathrm{~K}$ (for the references see above) as well as a Ring spectrum. For the multiplicative and additive polynomials, the same degrees were used as for the IO spectral retrieval. 


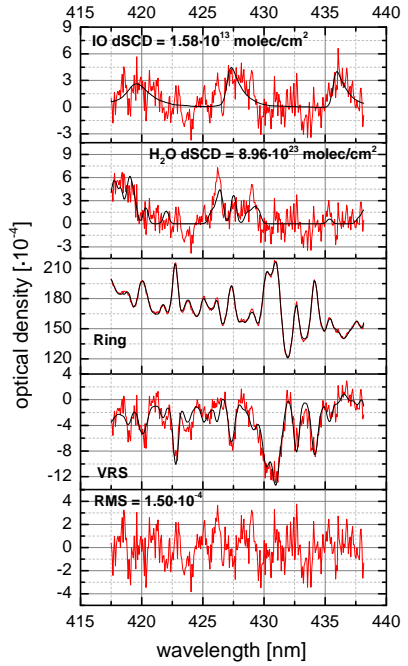

(a)

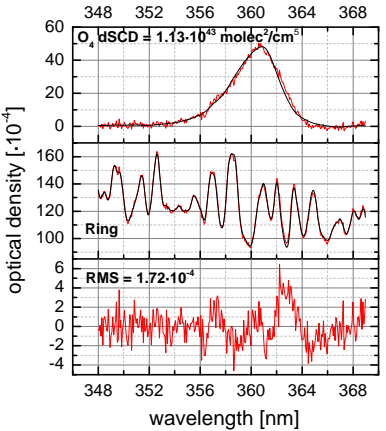

(b)

Fig. 1. Example for a spectral retrieval of (a) IO including a VRS compensation spectrum and (b) $\mathrm{O}_{4}$. The spectrum was recorded at an elevation angle of $3^{\circ}$, an SZA of $55.79^{\circ}$, at $19.87^{\circ} \mathrm{N}$ and $147.15^{\circ} \mathrm{W}$ and $15: 13$ local time (UTC $+10 \mathrm{~h}$ ) on 14 October 2009. The black lines indicate the fitted absorption cross-sections, whereas the red lines indicate the retrieved spectral signatures. The retrieved absorption structures of $\mathrm{NO}_{2}, \mathrm{O}_{3}, \mathrm{HCHO}$, and $\mathrm{BrO}$ are not shown.

Figure $1 \mathrm{~b}$ shows an example for an $\mathrm{O}_{4}$ spectral retrieval. In this case, the retrieved $\mathrm{O}_{4}$ dSCD was $1.13 \times$ $10^{43} \mathrm{molec}^{2} \mathrm{~cm}^{-5}$ with the RMS of the residual spectrum amounting to $1.72 \times 10^{-4}$.

For the further analysis, only data points with an RMS smaller than $4 \times 10^{-4}$ were used.

\subsection{Retrieval of aerosol and trace gas vertical profiles from MAX-DOAS measurements}

Vertical profiles of the aerosol extinction and IO mixing ratios were derived using the well-established method of optimal estimation (Rodgers, 2000). The aerosol and trace gas retrieval algorithm, as previously described by Frieß et al. (2006) and Frieß et al. (2011), was used and adapted for this study. Briefly, the optimal estimation method compared measured $\mathrm{O}_{4}$ and IO dSCDs with model simulations from radiative transfer modelling, using a priori vertical profiles as an additional constraint. The resulting maximum a posteriori (MAP) solutions yielded the aerosol extinction and IO mixing ratio profiles, respectively.

The following radiative transfer model parameters were chosen for both, the aerosol and the IO retrievals: pressure, temperature and humidity were adapted from the US standard atmosphere, and the surface albedo was set to $6 \%$. Profile information was retrieved for time intervals of $15 \mathrm{~min}$ for

individual layers, each $100 \mathrm{~m}$ in vertical extent, ranging from the surface up to $2000 \mathrm{~m}$ altitude.

\subsubsection{Details of the vertical profile retrieval}

In a first step, aerosol profiles were retrieved using a retrieval algorithm based on the SCIATRAN radiative transfer model (Rozanov et al., 2005). Since the length of the light paths and, thus, the $\mathrm{O}_{4}$ dSCDs observed at different elevation angles depend on the atmospheric aerosol loading, information on the aerosol extinction profile can be derived on the basis of the observed $\mathrm{O}_{4}$ dSCDs (Wagner et al., 2004; Sinreich et al., 2005; Frieß et al., 2006). As a priori, an aerosol extinction profile with a surface extinction of $0.14 \mathrm{~km}^{-1}$ and linearly decreasing to zero at an altitude of $2 \mathrm{~km}$ was chosen. The a priori error was set to $100 \%$. For aerosol scattering, an aerosol single scattering albedo of 0.95 and a HenyeyGreenstein phase function with an asymmetry parameter of 0.72 were assumed. $\mathrm{O}_{4}$ dSCDs inferred from different elevation angles from the $360.8 \mathrm{~nm}$ band served as measurement vector. According to findings by Clémer et al. (2010), the absorption cross-section of $\mathrm{O}_{4}$ was previously underestimated by as much as $25 \%$ and, hence, the $\mathrm{O}_{4}$ cross-section from Hermans et al. (1999) is multiplied by 1.25 .

IO vertical profiles were derived using our trace gas retrieval algorithm, which employed the McArtim Monte Carlo radiative transfer code as a forward model (Deutschmann et al., 2011). The retrieved extinction profiles from above served as input parameter for modelling the radiative transfer. The a priori IO profile was assumed to exponentially decrease with altitude, with a scale height of $1 \mathrm{~km}$ and a surface volume mixing ratio (VMR) of 2 ppt. The a priori error was set to $100 \%$ and the same $100 \mathrm{~m}$ layers as in the case of the aerosol retrieval were used. The profiles were simulated with $10^{4}$ photon trajectories.

For the measurements under clear skies on 14 October 2009, a comparison between measured and modelled $\mathrm{O}_{4}$ and IO dSCDs is shown in Fig. 2. A good agreement between modelled and measured dSCDs was achieved, showing that the radiative transfer model was able to reproduce the measurements with the chosen assumptions. Figure 3 shows average aerosol and IO averaging kernels. The aerosol and IO retrievals showed a distinctively different behaviour, with the aerosol retrieval being only sensitive to the lowermost $\approx 500 \mathrm{~m}$ of the atmosphere (note that the sensitivity varies with aerosol content due to the non-linear nature of the inverse problem). During the whole cruise the degrees of freedom for signal (DFS) of the aerosol retrieval ranged between 0.78 and 1.29 with an average value of 1.15 . Somewhat better sensitivity was achieved for the IO retrieval, where the averaging kernel indicated that information on the vertical profile was retrieved for the lowermost $1000 \mathrm{~m}$, and the DFS ranged between 1.30 and 2.26 with an average value of 1.97. 


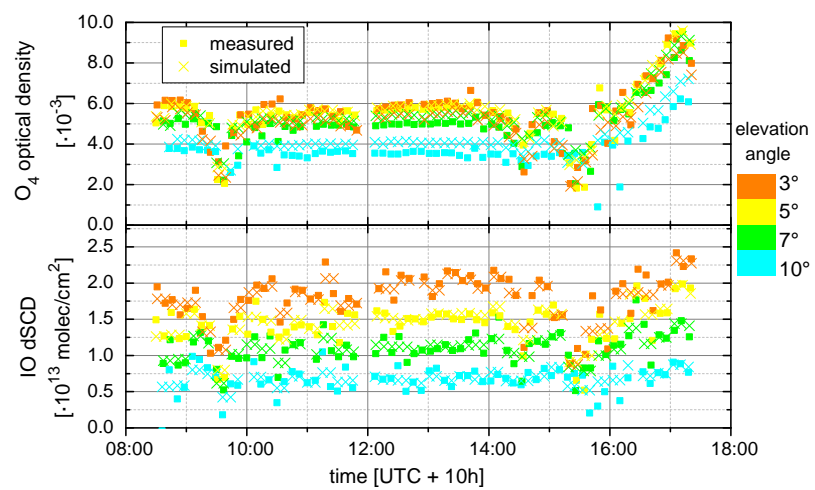

Fig. 2. Measured (squares) and simulated (crosses) $\mathrm{O}_{4}$ dSCDs (top) and IO dSCDs (bottom) for 14 October 2009. The colour coding indicates the elevation angles.

Figure 4 shows a comparison between the aerosol optical depth (AOD) retrieved from MAX-DOAS measurements and from data of a hand-held Sun photometer. Sun photometer data during the TransBrom Sonne cruise was very sparse and data was only available for several hours on six days. During these occasions, the AODs inferred from the MAX-DOAS and Sun photometer measurements showed good agreement except for 17 October 2009, when the AODs inferred from the Sun photometer observation were significantly lower than inferred from MAX-DOAS measurements.

\subsubsection{Error characterisation and information content}

Several sources contributed to the overall error of the retrieved profile. First, random and systematic errors (called noise error) of the trace gas spectral analysis propagated into the profile retrieval. Second, the limited information content of the measurements resulted in a limited height resolution as quantified by the averaging kernels, yielding the so-called smoothing error. Third, the uncertainty in the forward radiative model parameters caused a systematic error component. Furthermore, the choice of the a priori constraint affected the results of the retrieval. Since a detailed error analysis of the aerosol retrieval was already provided by Frieß et al. (2006), the focus of the following error discussion was put on the IO vertical profile retrieval.

The errors of the IO spectral analysis (noise error) were given by the IO fit error and the systematic errors. For example, for the measurement on 14 October 2009, the average (and typical) IO fit error was about $1.6 \times 10^{12}$ molec $^{-2}$ $(\approx 10 \%$ of the average IO dSCD) for an observation at an elevation angle of $3^{\circ}$.

In order to test the sensitivity of the spectral retrieval and of the forward model parameters on the profile retrieval, retrievals were performed for different sets of parameters. Table 4 specifies the different parameters and the corresponding inferred IO dSCDs, VMRs and VCDs and the respective

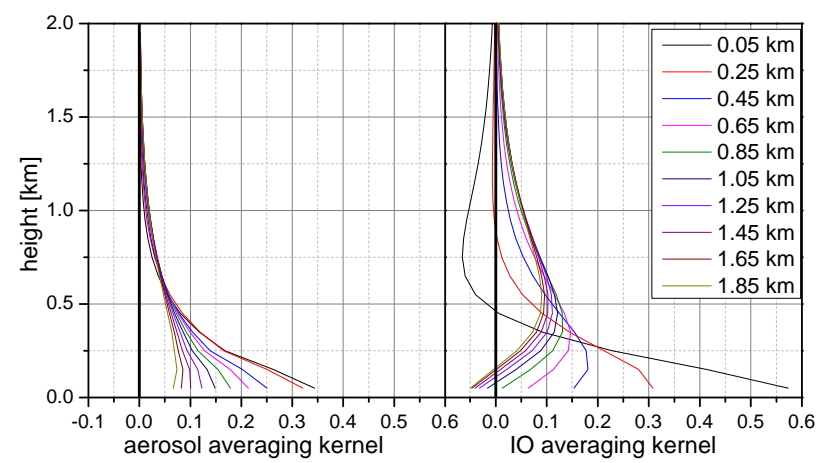

Fig. 3. Averaging kernels for inferred AOD and IO, both averaged for the data from all profile retrievals.

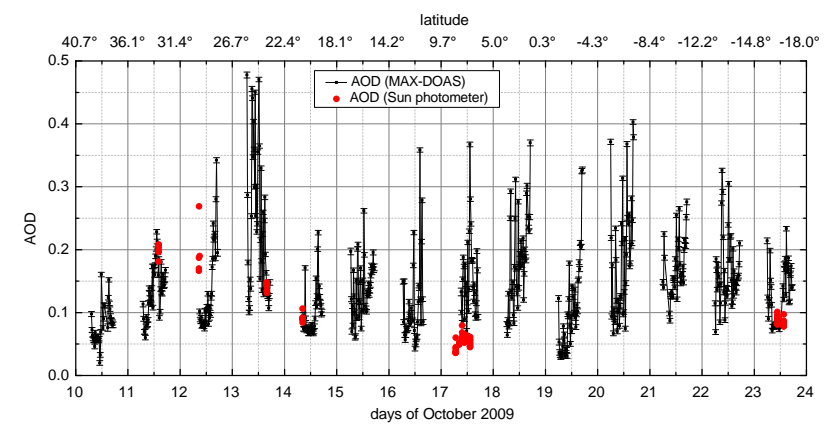

Fig. 4. Comparison of the aerosol optical depth (AOD) at $360 \mathrm{~nm}$ retrieved from MAX-DOAS (black squares) and from Sun photometer (red circles) measurements. The Sun photometer data were converted from AODs measurements at $440 \mathrm{~nm}$ to AODs at $360 \mathrm{~nm}$, using the Ångstrom exponents derived from the Sun photometer measurements.

absolute IO retrieval errors, averaged over many profile retrievals for a single day (14 October 2009). Systematic errors arose e.g., from excluding or including different absorption cross-sections in the DOAS fitting procedure. The following parameters were varied: (a) $\mathrm{An}_{2} \mathrm{O}$ absorption cross-section from HITRAN 2009 instead of HITRAN 2006 was included. Here it was found that the HITRAN $2009 \mathrm{H}_{2} \mathrm{O}$ yielded approximately $21 \%$ lower IO dSCDs and $12 \%$ lower dSCDs errors, most likely due to a wavelength shift of the HITRAN 2006 versus HITRAN $2009 \mathrm{H}_{2} \mathrm{O}$ absorption cross-section. (b) Inclusion of a glyoxal absorption cross-section in the spectral retrieval resulted in lower IO dSCDs $(\approx 19 \%)$, but much higher dSCD errors $(\approx 38 \%)$. (c) Inclusion or omission of a VRS compensation spectrum led to the results already stated above i.e., excluding the VRS compensation spectrum resulted in approximately $16 \%$ larger IO dSCDs and $25 \%$ larger dSCD errors.

The average VMR noise error of the final IO profile retrieval amounted to $0.3 \mathrm{ppt}$, which corresponded to approximately $25 \%$ of the average VMR of 1.3 ppt. However, here the smoothing error dominated the IO retrieval error and 
resulted in an average mixing ratio error of 0.8 ppt. Accordingly, the average total VMR error was 0.9 ppt.

The main uncertainty of the forward model parameter error was due to uncertainties in the assumed aerosol extinction profile. For example, changing the assumed AOD by $\pm 20 \%$, which was much larger than the typical total retrieval error of $5 \%$, modified the IO VMR by approximately $\pm 22 \%$.

A further test consisted of using an exponentially decreasing $\mathrm{IO}$ a priori profile with a scale height of again $1 \mathrm{~km}$ and a surface VMR of 1 or 4 ppt instead of 2 ppt. It was found that changing the a priori profile shape had a large impact on the shape of the inferred profile, which was a result of the limited information content of the profile retrieval.

Another error potentially arose from the uncertainty of the viewing direction. Assuming that the inclinometer did not correctly compensate for the rolling movement of the ship, an elevation offset of $1^{\circ}$ was implemented in the retrieval. Compared to the retrieval excluding an elevation offset the total VMR error was approximately $17 \%$ larger and the inferred VMR increased by $22 \%$.

In summary, the systematic error determined using a Gaussian square sum of the individual error components, amounted to $\approx 0.95 \times 10^{12}$ molec $\mathrm{cm}^{-2}(30 \%)$ and $0.65 \mathrm{ppt}$ $(60 \%)$ for the inferred IO VCD and VMR, respectively. The daily averaged DFS for 14 October 2009 was $d_{\mathrm{s}}=1.98$, but varied considerably with atmospheric visibility.

\subsection{Iodocarbons measurements}

Occasional air samples were collected using unpressurised canisters and analysed for major halocarbons using the GC/MS analytical system installed aboard. In addition, air samples were taken at higher frequency using pressurised canisters, which were analysed for halocarbons at the Rosenstiel School of Marine and Atmospheric Sciences (RSMAS) in Miami by the group of Elliot Atlas (Quack et al., 2013). Furthermore, a few air samples were analysed for some halocarbons at the Institute for Atmospheric and Environmental Sciences, University of Frankfurt, Germany by the group of Andreas Engel. All these samples, analysed at different laboratories, showed a good agreement for some brominated compounds (Brinckmann et al., 2012). The direct analysis of the samples analysed aboard the R/V Sonne with the GC/MS system was found to be necessary, since some iodinated halocarbons e.g., $\mathrm{CH}_{3} \mathrm{I}, \mathrm{CH}_{2} \mathrm{I}_{2}, \mathrm{CH}_{2} \mathrm{ClI}$ and $\mathrm{CH}_{2} \mathrm{BrI}$, are known to be unstable in the air canisters upon storage. Calibration of the on-board measurements was performed using liquid standards, since gaseous standards were not available. Three stock solutions of chlorinated, brominated and iodinated compounds were prepared in pentane, and volumetrically diluted with methanol to environmental concentrations. Analysis of the liquid standards was performed through the same analytical set-up as for seawater and atmospheric samples analysed on-board. Intercalibration of the analytical systems was performed with a) a NOAA gas standard mixture and b) with the $\mathrm{CHBr}_{3}$ and $\mathrm{CH}_{3} \mathrm{I}$ atmospheric data obtained by all three groups. The agreement between the two canister storage methods were generally better than $5 \%$, while the samples analysed with the on-board GC/MS system differed by as much as $20 \%$ in absolute terms, but generally showed a good agreement in relative terms. The iodinated compounds $\mathrm{CH}_{2} \mathrm{I}_{2}, \mathrm{CH}_{2} \mathrm{ClI}$ and $\mathrm{CH}_{2} \mathrm{BrI}$ were only calibrated with the standard solutions resulting in an estimated uncertainty of $20 \%$.

\subsection{Photochemical modelling}

The IO measurements were compared to simulations of the marine iodine chemistry performed with the onedimensional (1-D) photochemical model MISTRA v7.4.1 (von Glasow et al., 2002; Sommariva et al., 2012). MISTRA is a 1-D Lagrangian model which includes a detailed treatment of the dynamics and thermodynamics as well as a microphysical module that explicitly calculates particle growth and the interaction with radiation. MISTRA includes a detailed and recently updated gas and aqueous phase chemical mechanism, with a focus on halogen chemistry, as recently described in Sommariva and von Glasow (2012) and Sommariva et al. (2012).

The model was set up to simulate the transport of air masses in the MBL over the Pacific Ocean for a latitude of $10^{\circ} \mathrm{N}$ during October. The model meteorology was developed assuming a constant boundary layer height of $800 \mathrm{~m}$, and a surface wind speed and temperature of $6 \mathrm{~m} \mathrm{~s}^{-1}$ and $295 \mathrm{~K}$, respectively. These assumptions were based on the average meteorological observations made during the TransBrom cruise (Krüger and Quack, 2012), though sensitivity runs showed that the model results, with respect to iodine species, were not very sensitive to meteorological parameters under the conditions encountered during the TransBrom cruise.

Due to a lack of measurements during the campaign, the model was initialised based on previous measurements in a tropical remote region of the open ocean (Sommariva and von Glasow, 2012): $\mathrm{NO}_{\mathrm{x}} \approx 20 \mathrm{ppt}, \mathrm{O}_{3} \approx 30 \mathrm{ppb}$ and $\mathrm{CO}$ $\approx 130 \mathrm{ppb}$. The model was run for 1.5 days to spin-up the meteorology and the microphysics, then the chemistry was re-initialised and the model ran for another three days. The simulation represented a clean air mass that travelled for at least three days in the marine boundary layer of the tropical Western Pacific Ocean.

In model run 0 the only source of iodine was a mixture of iodinated hydrocarbons emitted from the ocean surface, according to the iodocarbon measurements. The flux of iodocarbons was calculated off-line, in order to reproduce the atmospheric observations of $\mathrm{CH}_{3} \mathrm{I}, \mathrm{CH}_{2} \mathrm{I}_{2}, \mathrm{CH}_{2} \mathrm{ClI}, \mathrm{CH}_{2} \mathrm{BrI}$, $\mathrm{C}_{2} \mathrm{H}_{5} \mathrm{I}, \mathrm{C}_{3} \mathrm{H}_{7} \mathrm{I}$ made during the TransBrom cruise (see Table 2). As $\mathrm{CH}_{2} \mathrm{ClI}$ was considerably elevated in cruise part 3 , the dataset was split into two separate model runs representative for the tropical region of cruise part 2 and with elevated 
Table 2. Iodocarbons measured during the TransBrom cruise. Since $\mathrm{CH}_{2} \mathrm{ClI}$ mixing ratios varied during the cruise, average values for cruise part 2 and part 3 were calculated.

\begin{tabular}{llllll}
\hline & $\mathrm{CH}_{3} \mathrm{I}$ [ppt] & $\begin{array}{l}\mathrm{CH}_{2} \mathrm{ClI} \\
\text { cruise part } \\
\text { [ppt] }\end{array}$ & $\begin{array}{l}\mathrm{CH}_{2} \mathrm{ClI} \\
\text { cruise part } 3 \\
{[\mathrm{ppt}]}\end{array}$ & $\mathrm{CH}_{2} \mathrm{BrI}$ [ppt] & $\mathrm{CH}_{2} \mathrm{I}_{2}$ [ppt] \\
\hline Lifetime & 6 days $^{1}$ & 0.1 days $^{2}$ & & $\approx 1 \mathrm{~h}^{3}$ & $2-10 \mathrm{~min}^{3}$ \\
\hline Average & 0.52 & 1.43 & 7.41 & 0.19 & $0.56^{1}$ \\
Minimum & 0.11 & 0.31 & 0.51 & 0.14 & 0.09 \\
Maximum & 0.93 & 4.162 & 13.85 & 0.25 & 1.76 \\
\hline $\begin{array}{l}\text { 1 Bell et al. (2002) } \\
\text { 2 }\end{array}$ & & & & \\
${ }^{3}$ Mattigan et al. (1997) & & & &
\end{tabular}

$\mathrm{CH}_{2} \mathrm{ClI}$ as during cruise part 3. Furthermore, two model runs with different levels of additional $\mathrm{I}_{2}$ fluxes as listed in Table 3 were performed (run 1 and 2).

The inferred iodocarbon fluxes were also compared to iodocarbon fluxes used in previous model studies: the fluxes from (a) Vogt et al. (1999) and from (b) von Glasow et al. (2002) were very similar, although they differ by a factor of two for the flux of $\mathrm{CH}_{2} \mathrm{ClI}$ and $\mathrm{C}_{3} \mathrm{H}_{7} \mathrm{I}$ (assumed as the sum of the two isomers). The flux of $\mathrm{CH}_{2} \mathrm{I}_{2}$ was assumed to be the same in both cases (Vogt et al. (1999) did not report a flux for this species). The ratios between the fluxes of the different species in both modelling studies were estimated based on the measurements of total organic iodine reported during field studies (Vogt et al. (1999) and references therein). A more recent study by Jones et al. (2010) reported observations of the sea-air fluxes of individual iodocarbons for (c) the open ocean region in the tropical and sub-tropical Atlantic Ocean and for (d) the Mauretanian upwelling region (high productivity region off the coast of West Africa). These fluxes were significantly different from previous estimates, particularly for the short-lived compounds such as $\mathrm{CH}_{2} \mathrm{I}_{2}$ and $\mathrm{CH}_{2} \mathrm{ClI}$, resulting in an overall weaker source of iodine in the remote ocean, even in high productivity regions (Table 3 ). The flux of $\mathrm{CH}_{2} \mathrm{ClI}$ in the Atlantic Ocean reported by Jones et al. (2010) is even ten times lower than the flux calculated for part 3 of the TransBrom cruise in the Western Pacific.

\section{Results and discussion}

Figure 5 shows the IO dSCDs for an elevation angle of $3^{\circ}$ together with the daily averaged IO dSCDs and the respective detection limits for the TransBrom cruise track. The average detection limit (assumed to be $2 \sigma$ ) was similar for all elevation angles and amounted to $S_{\min }=(3.32 \pm 0.72) \times 10^{12}$ molec $\mathrm{cm}^{-2}$ for an elevation angle of $3^{\circ}$. As expected the IO $\mathrm{dSCDs}$ increased with decreasing elevation angle, indicating that IO was present close to the surface, except for periods of heavy rain e.g., in the morning of 13 October 2009 and in the afternoon of 18 October 2009 as well as around noon on 20 to 22 October 2009. During these periods, no clear separation of the measured IO dSCDs for different elevation angles was observed owing to the low visibility. For rainy periods, the inferred IO dSCDs were also lower than on clear days. Compared to the measurements in cruise part 1 and 3 , in cruise part 2 the measured IO dSCDs were larger reaching typical IO dSCDs of $(1-1.8) \times 10^{13}$ molec $\mathrm{cm}^{-2}$ and maximum IO dSCDs of $2.5 \times 10^{13}$ molec $\mathrm{cm}^{-2}$. The largest IO dSCDs were observed on cloud free sunny days e.g., on 14 October 2009, but unfortunately due to software problems the early morning data were missing. Moreover, on days with almost clear sky and little cloud coverage, the measured IO dSCDs did not show a distinct diurnal cycle for SZAs lower than $84^{\circ}$. Contrary to this finding, on overcast days e.g., on 19 October 2009, enhanced IO dSCDs were observed for morning as compared to evening measurements. The enhanced IO dSCDs as well as the $\mathrm{O}_{4}$ dSCDs (not shown here) seen in the morning of 19 October are most likely caused by radiative transfer effects. On overcast days the length of the light path reaching the MAX-DOAS instrument changes a lot due to multiple scattering within clouds.

The inferred IO dSCDs were also compared to the measurements simultaneously taken with the Bremen instrument (for instrument description see Peters et al., 2012) for 14 October 2009 (Fig. 6). In order to avoid direct sunlight and detector saturation effects, the spectra from the IUP Bremen instrument were analysed against a single daily zenith Fraunhofer reference spectrum taken at an SZA of $45^{\circ}$, whereas for the IUP Heidelberg retrieval the $20^{\circ}$, spectrum taken during each elevation sequence was used as a Fraunhofer reference spectrum. For this comparison, however, the IO dSCDs from Heidelberg were also analysed against a single daily zenith Fraunhofer reference spectrum taken at an SZA of $45^{\circ}$. Overall, both datasets were in good agreement and the diurnal variations were similar for all days of the cruise. The Heidelberg IO dSCDs were found to be slightly higher than those inferred from the Bremen instrument. The difference was likely due to the different choice of reference spectra selected by both groups. Since both datasets showed an overall 
Table 3. Iodocarbon fluxes in units of $10^{7}$ molec $\mathrm{cm}^{-2} \mathrm{~s}^{-1}$ calculated from the data of previous studies and those collected during the TransBrom cruise part 2 and 3.

\begin{tabular}{lllllll}
\hline & $\begin{array}{l}\text { Vogt et al. } \\
(1999)\end{array}$ & $\begin{array}{l}\text { von Glasow et } \\
\text { al. (2002) }\end{array}$ & $\begin{array}{l}\text { Jones et al. } \\
(2010) \\
\text { open ocean }\end{array}$ & $\begin{array}{l}\text { Jones et al. } \\
(2010) \\
\text { welling }\end{array}$ & $\begin{array}{l}\text { TransBrom } \\
\text { cruise part 2 }\end{array}$ & $\begin{array}{l}\text { TransBrom } \\
\text { cruise part 3 }\end{array}$ \\
\hline $\mathrm{CH}_{3} \mathrm{I}$ & 0.6 & 0.6 & 3.4 & 3.6 & 0.48 & 0.48 \\
$\mathrm{CH}_{2} \mathrm{I}_{2}$ & 3.0 & 3.0 & 1.3 & 1.4 & 2.3 & 2.3 \\
$\mathrm{CH}_{2} \mathrm{ClI}$ & 3.0 & 6.0 & 1.2 & 1.9 & 3.8 & 19.0 \\
$\mathrm{CH}_{2} \mathrm{BrI}$ & 0.0 & 0.0 & 0.76 & 0.59 & 0.71 & 0.71 \\
$\mathrm{CH}_{2} \mathrm{H}_{5} \mathrm{I}$ & 0.0 & 0.0 & 0.29 & 0.38 & $0.38^{2}$ & $0.38^{2}$ \\
$\mathrm{CH}_{3} \mathrm{H}_{7} \mathrm{I}$ & 2.0 & 1.0 & 0.063 & 0.056 & $0.063^{2}$ & $0.063^{2}$ \\
Additional I flux (run 1) & - & - & 22.0 & 19.0 & 18.0 & 10.0 \\
Additional $\mathrm{I}_{2}$ flux (run 2) & - & - & 22.0 & 19.0 & 34.0 & 16.0 \\
\hline
\end{tabular}

1 Used the same value as $\mathrm{CH}_{2} \mathrm{ClI}$;

2 not measured during TransBrom. The highest fluxes reported by Jones et al. (2010) are used.

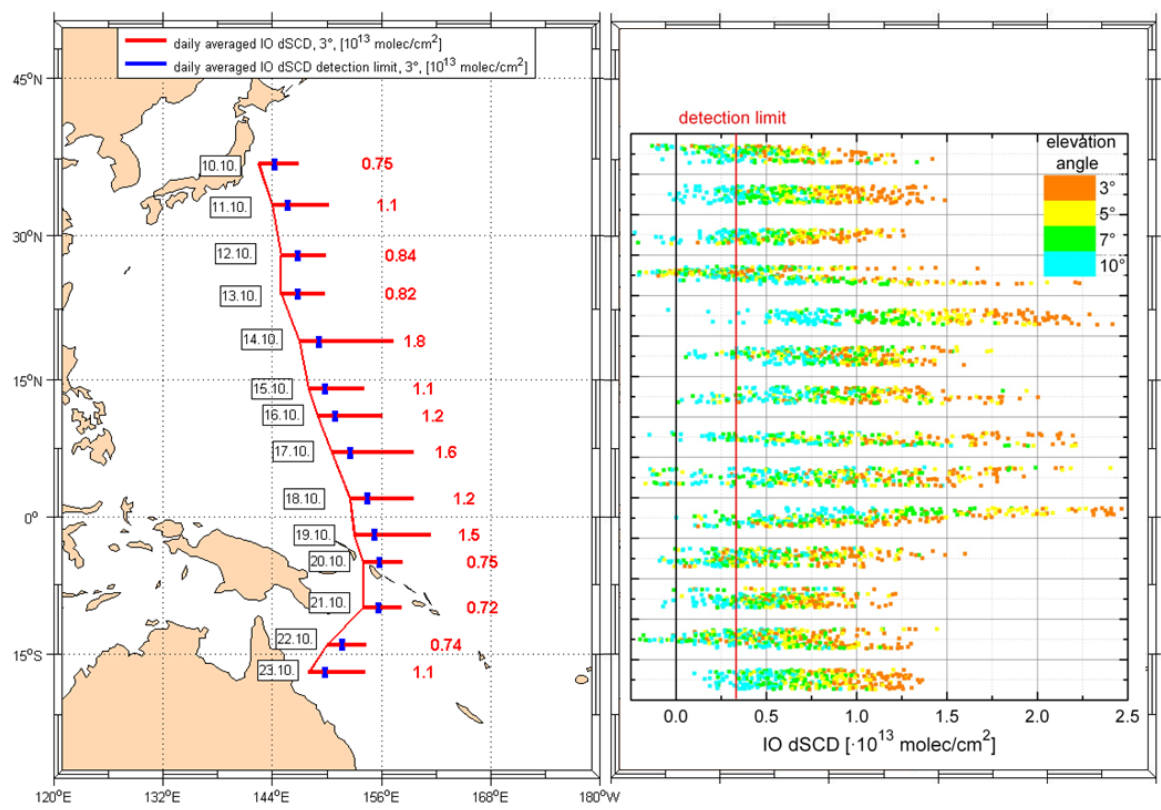

Fig. 5. Daily averaged IO dSCDs measured for elevation angles of $3^{\circ}$ (red) along the cruise track with the dSCD detection limits displayed by blue bars (left panel). In the right panel, all inferred IO dSCDs are shown and colour-coded for different elevation angles.

good agreement, for further analysis only the Heidelberg IO dSCDs were used.

A latitudinal cross-section of inferred daily averaged IO VCDs and IO surface mixing ratios is shown in panel a of Fig. 7. In general, the retrieved IO surface mixing ratios were subject to significantly larger relative errors than the VCDs, because the measurements yielded only limited information on the shape of the IO profile, whereas the VCD was retrieved with significantly better accuracy. Largest IO VCDs and IO surface mixing ratios were present during cruise part $2\left(20^{\circ} \mathrm{N}\right.$ to $\left.5^{\circ} \mathrm{S}\right)$, where the daily averaged VCD reached

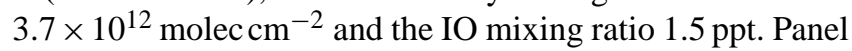
b of Fig. 7 shows the air mixing ratios of the organic io- dine precursor molecules $\mathrm{CH}_{3} \mathrm{I}, \mathrm{CH}_{2} \mathrm{BrI}, \mathrm{CH}_{2} \mathrm{I}_{2}$ and $\mathrm{CH}_{2} \mathrm{ClI}$. They indicate that the largest iodocarbon mixing ratios occurred in the southern tropical hemisphere. Furthermore, after 21 October 2009 (cruise part 3), a significant increase in $\mathrm{CH}_{2} \mathrm{ClI}$ was observed, when the R/V Sonne passed Papua New Guinea and approached the north coast of Australia, where the increased biological activity was largely due to the proximity to the coast. Accordingly, biologically derived iodocarbons e.g., $\mathrm{CH}_{2} \mathrm{ClI}$ reached mixing ratios of more than $12 \mathrm{ppt}$ near the surface. Due to its short lifetime (some hours), $\mathrm{CH}_{2} \mathrm{ClI}$ was potentially an efficient source of inorganic iodine there, but surprisingly a corresponding increase in IO was not observed. Table 5 shows an overview of the 
Table 4. Overview of retrieved quantities and their errors for different IO retrieval settings, averaged over all observations from 14 October 2009. The scenario in the first column (bold) corresponds to the optimal parameters found for the spectral retrieval. The basic parameters and settings are described in Sects. 3.3 and 3.4. The dSCDs are given in units of $10^{13}$ molec $\mathrm{cm}^{-2}$, the VCDs in units of $10^{12} \mathrm{molec} \mathrm{cm}^{-2}$ and the VMR in ppt.

\begin{tabular}{|c|c|c|c|c|c|c|c|c|c|}
\hline parameter & $\begin{array}{l}\mathrm{H}_{2} \mathrm{O} \\
2009\end{array}$ & $\begin{array}{l}\mathrm{H}_{2} \mathrm{O} \\
2006\end{array}$ & $\begin{array}{l}\text { with gly- } \\
\text { oxal }\end{array}$ & $\begin{array}{l}\text { without } \\
\text { VRS }\end{array}$ & $\begin{array}{l}\text { apriori } \\
1 \mathrm{ppt}\end{array}$ & $\begin{array}{l}\text { apriori } \\
4 \mathrm{ppt}\end{array}$ & $\begin{array}{l}\text { AOD } \\
+20 \%\end{array}$ & $\begin{array}{l}\text { AOD } \\
-20 \%\end{array}$ & $\begin{array}{l}\alpha \text { offse } \\
1^{\circ}\end{array}$ \\
\hline $\mathrm{dSCD} 3^{\circ}$ & 1.880 & 2.268 & 1.521 & 2.173 & - & - & - & - & - \\
\hline$\triangle \mathrm{dSCD} 3^{\circ}$ & 0.157 & 0.175 & 0.217 & 0.196 & - & - & - & - & - \\
\hline VMR & 1.290 & 1.674 & 1.023 & 1.668 & 1.178 & 1.410 & 1.574 & 0.998 & 1.491 \\
\hline VMR noise error & 0.323 & 0.305 & 0.340 & 0.333 & 0.231 & 0.553 & 0.321 & 0.326 & 0.446 \\
\hline VMR smoothing error & 0.830 & 0.842 & 0.856 & 0.835 & 0.451 & 1.551 & 0.787 & 0.904 & 0.940 \\
\hline VMR total error & 0.893 & 0.897 & 0.923 & 0.902 & 0.508 & 1.654 & 0.852 & 0.963 & 1.043 \\
\hline VCD & 3.383 & 3.980 & 3.089 & 3.725 & 3.001 & 3.729 & 3.530 & 3.266 & 3.823 \\
\hline VCD noise error & 0.296 & 0.284 & 0.321 & 0.297 & 0.230 & 0.380 & 0.320 & 0.277 & 0.348 \\
\hline VCD smoothing error & 0.315 & 0.309 & 0.323 & 0.305 & 0.209 & 0.542 & 0.359 & 0.270 & 0.307 \\
\hline VCD total error & 0.434 & 0.422 & 0.457 & 0.428 & 0.311 & 0.665 & 0.482 & 0.388 & 0.465 \\
\hline degrees of freedom & 1.983 & 1.985 & 1.931 & 1.986 & 1.721 & 2.247 & 1.995 & 1.968 & 1.803 \\
\hline AOD & 0.093 & 0.093 & 0.093 & 0.093 & 0.093 & 0.093 & 0.111 & 0.074 & 0.097 \\
\hline
\end{tabular}

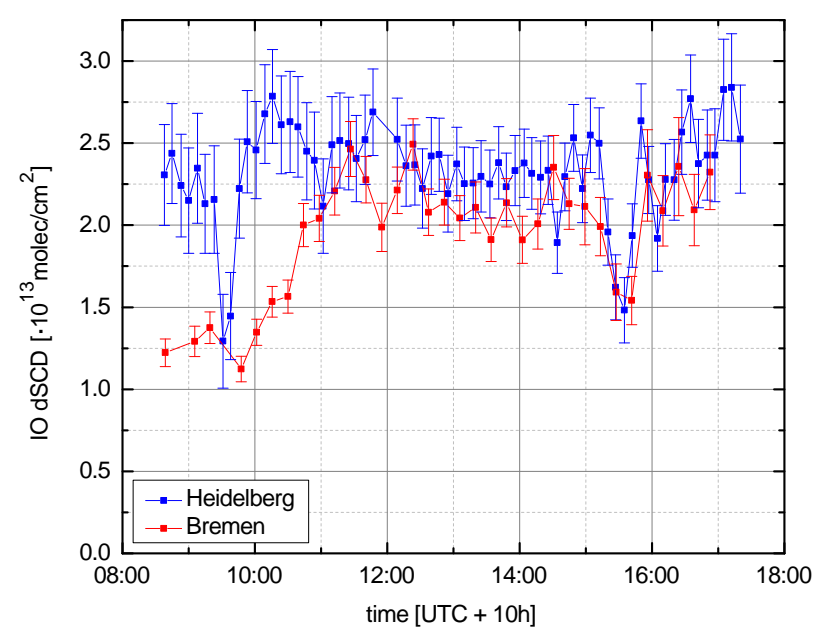

Fig. 6. Comparison of IO dSCDs retrieved from $5^{\circ}$ elevation angle observations of the Bremen (red) and the Heidelberg (blue) instruments on 14 October 2009. Since the Bremen instrument performed more elevation angles per sequences, observations at specific elevation angles are less frequent.

different parameters that were correlated with the daily averaged IO mixing ratios. Except for $\mathrm{CH}_{2} \mathrm{BrI}$, the daily averaged iodocarbons only indicate a weak correlation with daily averaged IO VMR $(R \leq \pm 0.25)$, supporting the idea that organic iodocarbons were not the main source for reactive iodine in the MBL. Note that for $\mathrm{CH}_{2} \mathrm{BrI}$ only three data points were available. Hence, a reliable correlation could not be obtained. Furthermore, the daily averaged oceanic Chl $a$ content (Zindler et al., 2012) and the IO VMR were found to be anti-correlated with a correlation coefficient of $R=-0.70$. Thus, the oceanic Chl $a$ concentrations (panel c of Fig. 7) may not serve as a good proxy for the presence of IO in the MBL. Zeaxanthin and divinyl chlorophyll $a$ are marker pigments for cyanobacteria (Zindler et al., 2012). Since both marker pigments only show a weak anti-correlation with IO VMR ( $R=-0.42, R=-0.43)$, they may also not serve as an appropriate indicator for IO.

In the latitude band between $15^{\circ} \mathrm{N}$ and $8^{\circ} \mathrm{S}$, ozone mixing ratios measured by in-situ $\mathrm{O}_{3}$-sondes (Markus Rex, AWI Potsdam, personal communication) dropped to values close to zero near the surface (panel d of Fig. 7). Since the $\mathrm{O}_{3}$ and IO mixing ratios anti-correlated with $R=-0.47$, this may lead to the conclusion that ozone was lost by iodinemediated photochemistry or in reactions with dissolved organic matter at the ocean surface, a finding in broad agreement with recently reported results from the Eastern Pacific (Mahajan et al., 2012). At the same time reactions of ozone with dissolved organic matter (DOM) at the ocean surface could have initiated the release of iodocarbons into the atmosphere. When ozone reacts with dissolved iodide, hypoiodous acid HOI and molecular iodine $\left(\mathrm{I}_{2}\right)$ are formed at the ocean surface (e.g., Garland et al., 1980; Carpenter et al., 2013). HOI and $I_{2}$ further react with DOM to produce dissolved organic iodine (DOI). Iodocarbons can then be produced from the oxidation of iodide by ozone and the reaction of HOI with organic molecules (Garland et al., 1980; Garland and Curtis, 1981; Martino et al., 2009). However, owing to the poor correlation between the IO and ozone mixing ratio found in the data, a tighter conclusion can neither be drawn on ozone destruction by reactive iodine, nor on an ozone-driven iodine precursor production. Further, IO showed a positive correlation with relative humidity $(R=0.60)$ (panel d of Fig. 7) and with sea surface temperature (SST) $(R=0.71)$ (panel $\mathrm{c}$ of Fig. 7). The latter correlation might point to an increased oceanic release 
Table 5. Overview of the correlation of different parameters with IO mixing ratios (daily averages).

\begin{tabular}{|c|c|c|c|}
\hline correlation parameters & $\begin{array}{l}\text { number of } \\
\text { data points }\end{array}$ & $\begin{array}{l}\text { correlation } \\
\text { coefficient }\end{array}$ & $\begin{array}{r}\text { Pearson } \\
\text { slope of linear } \\
\text { correlation }\end{array}$ \\
\hline $\mathrm{CH}_{3} \mathrm{I}[\mathrm{ppt}]$ & 7 & 0.25 & 0.150 \\
\hline $\mathrm{CH}_{2} \mathrm{ClI}[\mathrm{ppt}]$ & 10 & -0.22 & -0.023 \\
\hline $\mathrm{CH}_{2} \mathrm{BrI}[\mathrm{ppt}]$ & 3 & -0.91 & -5.320 \\
\hline $\mathrm{CH}_{2} \mathrm{I}_{2}[\mathrm{ppt}]$ & 8 & 0.15 & 0.220 \\
\hline Chl $a\left[\mathrm{mg} \mathrm{m}^{-3}\right]$ & 14 & -0.70 & -0.001 \\
\hline zeaxanthin $\left[\mathrm{mg} \mathrm{m}^{-3}\right]$ & 14 & -0.42 & -0.005 \\
\hline $\begin{array}{l}\text { divinyl chlorophyll } a \\
{\left[\mathrm{mg} \mathrm{m}^{-3}\right]}\end{array}$ & 14 & -0.43 & -0.004 \\
\hline $\mathrm{O}_{3}[\mathrm{ppb}]$ & 12 & -0.47 & -0.009 \\
\hline humdity [\%] & 14 & 0.60 & 0.021 \\
\hline $\mathrm{SST}\left[{ }^{\circ} \mathrm{C}\right]$ & 14 & 0.71 & 0.076 \\
\hline windspeed $\left[\mathrm{m} \mathrm{s}^{-1}\right]$ & 14 & -0.31 & -0.031 \\
\hline
\end{tabular}

of iodocarbons due to their decreasing solubility at higher temperatures. Moreover, the Pearson correlation coefficient of wind speed and IO amounts to $R=-0.30$ (see Table 5) indicating that a correlation e.g., during the tropical storms was not observed. The relative humidity and wind speed were recorded by the weather station of the R/V Sonne, whereas the SST was measured by a factory calibrated temperature probe in surface seawater taken from $5 \mathrm{~m}$ depth in the hydrographic shaft of the R/V Sonne.

\section{Comparison to model calculations}

The measurements are compared to results obtained from the MISTRA model simulations (see Sect. 3.6). Due to the limited vertical resolution of the IO profiles retrieved from the MAX-DOAS measurements, a quantitative comparison of measured and modelled IO required the artificial degradation of the modelled profiles i.e., by applying the inferred averaging kernel according to Rodgers and Connor (2003),

$\boldsymbol{x}^{\prime}=\boldsymbol{x}_{\mathrm{a}}+\mathbf{A}\left(\boldsymbol{x}-\boldsymbol{x}_{\mathrm{a}}\right)$

where $\boldsymbol{x}$ is the modelled IO vertical profile, A the MAXDOAS averaging kernel and $x_{\mathrm{a}}$ the MAX-DOAS a priori profile. The artificially degraded profile $\boldsymbol{x}^{\prime}$ represents the vertical profile that would have been retrieved from the MAXDOAS measurements if the true profile would be $\boldsymbol{x}$. Since the MAX-DOAS averaging kernel varied from profile retrieval to profile retrieval, due to changes in atmospheric visibility and aerosol load, a representative averaging kernel matrix $\mathbf{A}$ was calculated from the mean of all inferred averaging kernels (see Fig. 3).

Figure 8 shows the IO VCDs derived from the different model scenarios as listed in Table 3, together with the measured VCDs as a function of SZA and averaged for all data taken during the cruise. For all model runs the adjusted modelled VCDs were significantly larger than the unmodified

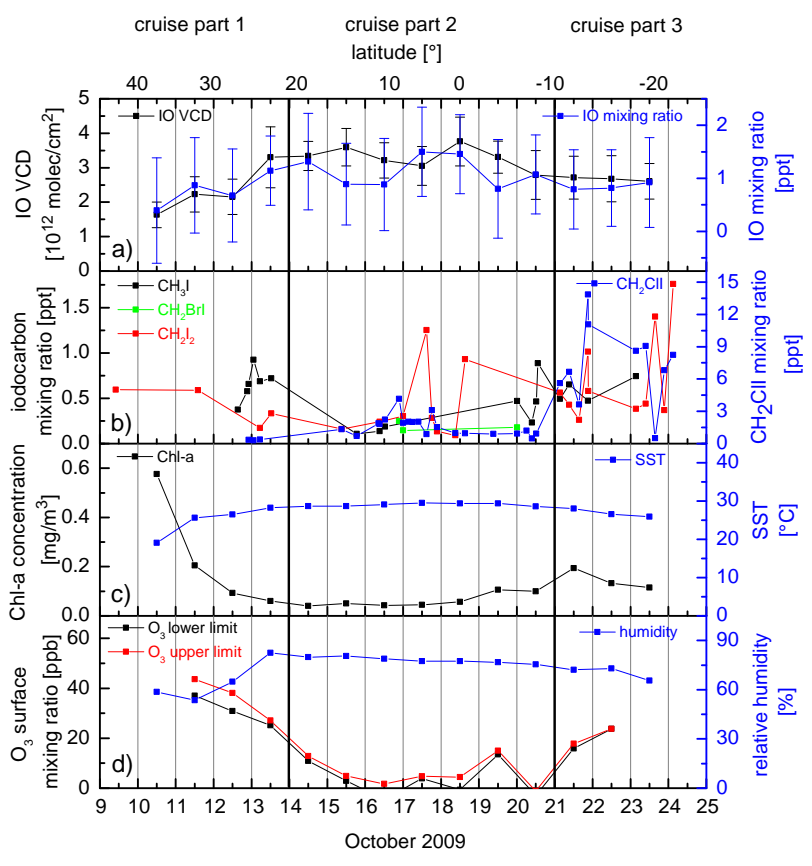

Fig. 7. Latitudinal cross-section of daily averaged IO VCDs and mixing ratios with the error bars indicating the respective daily averaged total error (a), iodocarbon mixing ratios (b), daily averaged Chl $a$ concentration and sea surface temperature (SST) (c) as well as the $\mathrm{O}_{3}$ mixing ratios averaged for the lowest $100 \mathrm{~m}$ from each of the different $\mathrm{O}_{3}$-sonde profiles (upper limit of the uncertainty range in red and lower limit of the uncertainty range in black), and the daily averaged relative humidity (d).

modelled VCDs. This positive bias was caused by the choice of the a priori, which exponentially decreased with altitude and, therefore, contained some residual IO located above the model boundary layer i.e., at altitudes where the sensitivity of the MAX-DOAS measurements was very limited.

The diurnal variation of the modelled IO VCD was distinctively different for the model runs excluding (run 0 ) or including an additional $\mathrm{I}_{2}$ source (run 1 and 2). In particular, the model runs including an $\mathrm{I}_{2}$ source exhibited larger $\mathrm{IO}$ $\mathrm{VCDs}$ in the morning (maximum at $\approx 73^{\circ} \mathrm{SZA}$ ), whereas the model run 0 (excluding an $\mathrm{I}_{2}$ source) showed a symmetric diurnal variation. Thus, the IO peak mixing ratio in the morning resulted from the rapidly photolysed $\mathrm{I}_{2}$ (Saiz-Lopez and Plane, 2004) that had accumulated in the MBL during the night. It was found that an additional $\mathrm{I}_{2}$ flux of at least $j_{\mathrm{I}_{2}}=1.8 \times 10^{8} \mathrm{molec} \mathrm{cm}^{-2} \mathrm{~s}^{-1}$ (run 1) was required to reproduce the measurements of cruise part 2 . The artificially degraded VCDs of model run 0 excluding an additional $\mathrm{I}_{2}$ source were $(1-1.5) \times 10^{12}$ molec $\mathrm{cm}^{-2}$, which was outside the error of the measurements supporting the conclusion that an additional iodine flux is required.

In the absence of an $I_{2}$ source (run 0), the model predicted approximately twice as much IO in the MBL for part 3 as compared to part 2, mostly owing to the higher 


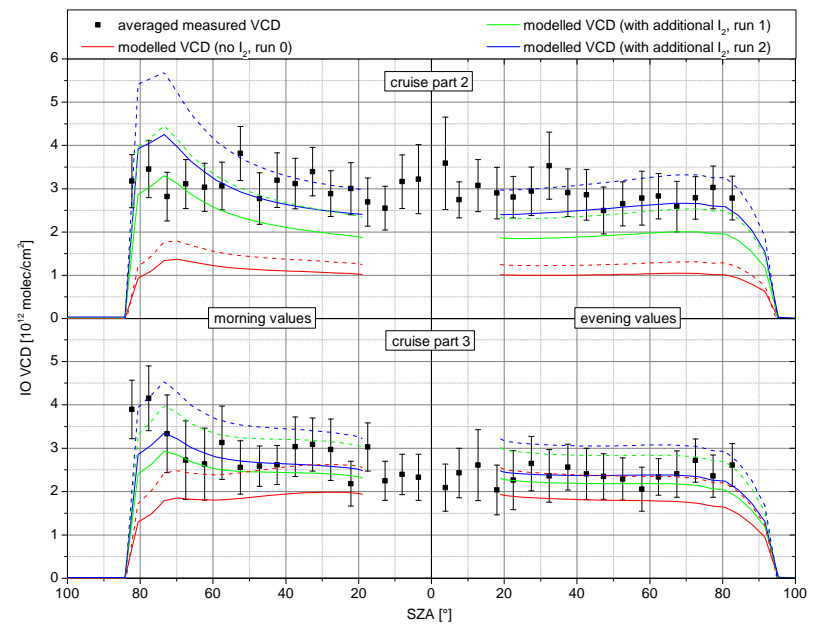

Fig. 8. Comparison of morning (left panel) and evening (right panel) values of measured and modelled IO VCDs as a function of SZA for the cruise part 2 (upper panel) and for the cruise part 3 (lower panel). The modelled VCDs are calculated from predictions of model runs 0, 1 and 2, according to Table 3 (solid red, green and blue lines) and the corresponding artificially degraded model VCDs are indicated by dashed lines. The measured VCDs are $5^{\circ} \mathrm{SZA}$ averages for the cruise part 2 and 3 (black squares), respectively.

iodocarbon mixing ratios there. The additional $\mathrm{CH}_{2} \mathrm{ClI}$ observed in cruise part 3 causes an increase in the modelled IO VCDs of about $1 \times 10^{12}$ molec $\mathrm{cm}^{-2}$ compared to cruise part 2 , whereas $I_{2}$ contributes with about $(0.5-1) \times$ $10^{12}$ molec $\mathrm{cm}^{-2}$. In this case the comparison of modelled and measured VCDs did not allow us to decide, if an additional $\mathrm{I}_{2}$ source was required. However, the measurements showed elevated IO VCDs for SZAs larger than $70^{\circ}$, which were indicative for the presence of a short-lived inorganic iodine precursor e.g., $\mathrm{I}_{2}$.

Panel a-d of Fig. 9 show the modelled vertical profiles of IO for run 0 and 1. Except for the early morning hours, IO was predicted to be well mixed within the boundary layer in run 0 (panel a and b of Fig. 9), mainly as a result of the relatively long photochemical lifetime of the iodocarbons (see Table 2). In contrast, for run 1 (including an $\mathrm{I}_{2}$ source) (panel $c$ and d of Fig. 9), IO shows a strong vertical gradient with highest IO mixing ratios near the surface. Figure 10 shows the single vertical profiles of model run 0 and 1 for cruise part 2 and 3 at noon, respectively. In model run 1 the shallow layer of enhanced IO with a strong vertical gradient near the surface is clearly visible.

Panels e-h of Fig. 9 show the same model scenarios as in panel $\mathrm{a}-\mathrm{d}$, but artificially degraded with the MAX-DOAS averaging kernel. As expected, the adjusted profiles showed much larger vertical gradients as a result of the limited vertical resolution of the MAX-DOAS measurements. However, the main features of the model run 0 and 1 were still discernable in the artificially degraded profiles. In particular, the ar-

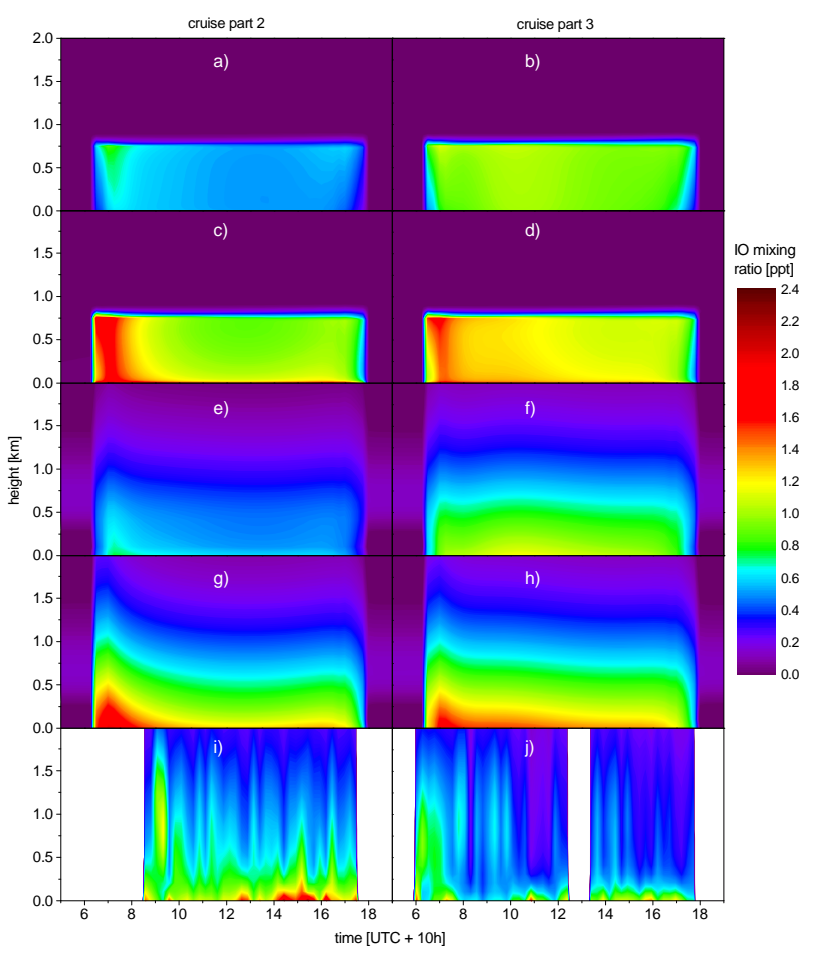

Fig. 9. IO simulations of the MISTRA model (a-h) and inferred IO profiles from the MAX-DOAS measurements $(\mathbf{i}, \mathbf{j})$ for a typical scenario of cruise part 2 (left column) and cruise part 3 (right column). Panels (a) and (b) excluding an additional inorganic iodine flux, (c) and (d) including an additional $\mathrm{I}_{2}$ flux of $j_{\text {part }} 2=$ $1.8 \times 10^{8}$ molec cm $^{-2} \mathrm{~s}^{-1}$ and $j_{\text {part } 3}=1.0 \times 10^{8}$ molec cm $^{-2} \mathrm{~s}^{-1}$, respectively, (e)-(h) same as (a)-(d), but artificially degraded, (i) and (j) retrieved from the MAX-DOAS measurements for 14 October 2009 and for 23 October 2009, respectively. The colour coding represents IO mixing ratios in units of ppt.

tificially degraded profiles of run 1 showed a shallow layer of enhanced IO located directly above the surface.

Panel $i$ of Fig. 9 shows the IO mixing ratios retrieved from the MAX-DOAS measurements during cruise part 2 on 14 October 2009, and panel j for 23 October 2009 during cruise part 3. These two days had the lowest cloud contamination of the IO profile retrieval. For both days, the measured IO profiles were similar to the prediction of model run 1 , with IO being distributed over the entire depth of the boundary layer in the morning i.e., in particular seen on 23 October 2009. During the rest of this day IO was confined within a shallow layer near the surface of about $300 \mathrm{~m}$ in vertical extent. These findings strongly supported the hypothesis that an additional short-lived inorganic iodine compound was necessary to find a good agreement between measured and modelled IO. 


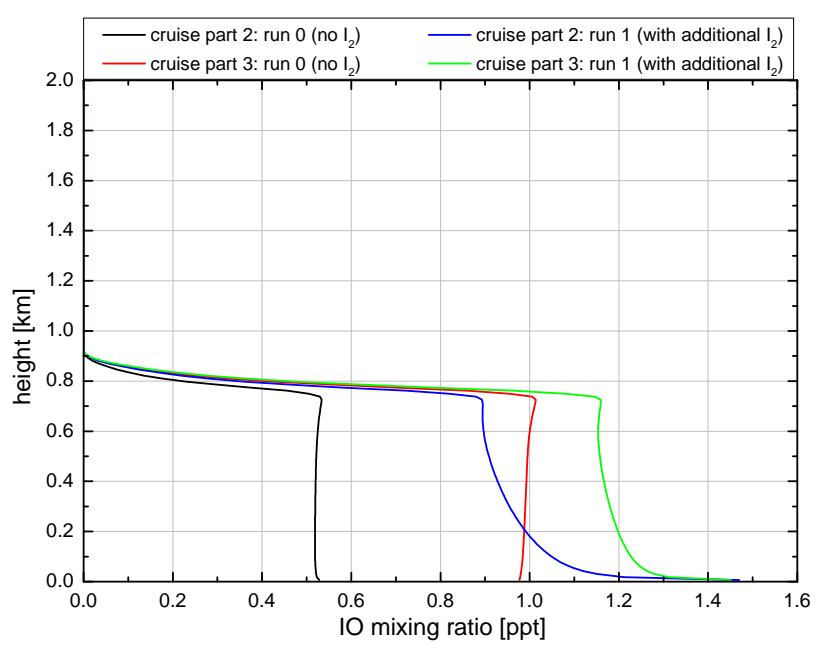

Fig. 10. IO vertical profiles for different model scenarios (run 0, run 1) for cruise part 2 and 3 at 12:00 local time.

\section{Conclusions}

The present paper reports on a latitudinal cross-section of surface IO mixing ratios and IO profiles, which were taken in the MBL of the Western Pacific $\left(42^{\circ} \mathrm{N}, 141^{\circ} \mathrm{E}\right.$ to $19^{\circ} \mathrm{S}$, $\left.146^{\circ} \mathrm{E}\right)$. The measurements provide further evidence that IO is probably ubiquitous in the marine environment, with slightly enhanced IO being detected above warmer tropical (cruise part 2) as compared to the adjacent colder waters (cruise parts 1 and 3). The IO profiles inferred from the MAX-DOAS measurements indicate that (a) the bulk of IO with mixing ratios in the range (1-2.2) ppt was located in a shallow layer near the surface of less than $300 \mathrm{~m}$ in vertical extent during the day and that (b) IO is more widely distributed in the MBL in the morning.

A negative correlation of oceanic $\mathrm{Chl} a$ and atmospheric IO was observed in agreement with a recent study performed in the Eastern Pacific (Mahajan et al., 2012). Both studies are providing strong evidence that, in contrast to coastal regions where iodocarbon emissions of macroalgae are likely the major source for iodine (e.g. Seitz et al., 2010; Commane et al., 2011), in the open ocean direct marine emissions of inorganic iodine (here assumed to be $\mathrm{I}_{2}$ ) are important as a source of reactive iodine in the MBL, in line with recent findings of Carpenter et al. (2013).

This conclusion is corroborated by the following findings of our study:

1. There is no correlation between the measured $\mathrm{IO}$ and the organic iodine precursor species $\mathrm{CH}_{3} \mathrm{I}, \mathrm{CH}_{2} \mathrm{ClI}, \mathrm{CH}_{2} \mathrm{BrI}$ and $\mathrm{CH}_{2} \mathrm{I}_{2}$.

2. The observed IO is underpredicted by the MISTRA model when only using iodocarbons as iodine precursors.
3. In the morning the IO peak is much smaller in the MBL, when excluding a strong inorganic iodine source, e.g., $\mathrm{I}_{2}$, in the MISTRA model.

4. Over the course of the day IO tends to be confined to a shallow layer of enhanced IO near the surface, requiring a short-lived precursor molecule emitted from the ocean, e.g., $\mathrm{I}_{2}$, with a flux of 1.0 to $1.8 \times 10^{8} \mathrm{molec} \mathrm{cm}^{-2} \mathrm{~s}^{-1}$.

Findings 1 and 2 are in agreement with those previously reported by Jones et al. (2010) and Mahajan et al. (2010a).

Possible mechanisms for the direct oceanic emission of $\mathrm{I}_{2}$ include (a) the reaction of ozone with dissolved organic matter at the ocean surface, as proposed by Garland and Curtis (1981) and Martino et al. (2009), (b) emission from any other abiotic source in the surface water body (Garland and Curtis, 1981; McFiggans, 2005; Carpenter et al., 2013), (c) direct emission of $I_{2}$ produced by microalgae and phytoplankton ( $\mathrm{I}_{2}$ emissions by macroalgae in coastal regions was observed at several sites, e.g., by Peters et al., 2005; Saiz-Lopez and Plane, 2004; and Finley and Saltzman, 2008), and (d) iodine liberated from the sea salt aerosol (e.g. Saiz-Lopez et al., 2012). Mechanism (c) is unlikely due to the anti-correlation between IO and Chl $a$ and the lack of any correlation between IO and the organic iodine precursor species. While mechanism (d) is already implemented in the MISTRA model, our study does not give hints as to whether mechanism (a) and (b) are more relevant for our observations and for open ocean iodine emissions in general. However, there are still uncertainties regarding e.g., the heterogeneous and aqueous phase processes, and the iodine release mechanism might be underpredicted by the model (e.g., Reeser et al., 2009; Jammoul et al., 2009).

Acknowledgements. This study has been partly funded by the national WGL project TransBrom. The ship campaign on $\mathrm{R} / \mathrm{V}$ Sonne was supported by the BMBF (German Federal Ministry of Education and Research) through grant 03G0731A. Additional funding from the project EU-SHIVA (FP7-ENV-2007-1-226224) and from the project SOPRAN (03F0462F) (funded by BMBF, the German Federal Ministry of Education and Research) is highly acknowledged. Many thanks also to Markus Rex from the Alfred Wegener Institut (AWI) Potsdam for preparing the ozone data and to Tilman Dinter from the Institut für Umweltphysik (IUP) Bremen for the VRS compensation spectrum. We further acknowledge the PHYTOOPTICS group from AWI Bremerhaven and IUP Bremen for providing the $\mathrm{Chl} a$ data.

Edited by: W. T. Sturges 


\section{References}

Allan, B. J., McFiggans, G., and Plane, J. M. C.: Observation of iodine monoxide in the remote marine boundary layer, J. Geophys. Res., 105, 14363-14369, doi:10.1029/1999JD901188, 2000.

Bell, N., Hsu, L., Jacob, D. J., Schultz, M. G., Blake, D. R., Butler, J. H., King, D. B., Lobert, J. M., and Maier-Reimer, E.: Methyl iodide: Atmospheric budget and use as a tracer of marine convection in global models, J. Geophys. Res., 107, 4340, doi:10.1029/2001JD001151, 2002.

Bogumil, K., Orphal, J., and Burrows, J. P.: Temperature-dependent absorption cross-sections of $\mathrm{O}_{3}, \mathrm{NO}_{2}$, and other atmospheric trace gases measured with the SCIAMACHY spectrometer, in: Proceedings of the ERS-Envisat Symposium, Gothenburg, Sweden, 2000.

Bonazzola, M. and Haynes, P.: A trajectory-based study of the tropical tropopause region, J. Geophys. Res., 109, D20112, doi:10.1029/2003JD004356, 2004.

Brinckmann, S., Engel, A., Bönisch, H., Quack, B., and Atlas, E.: Short-lived brominated hydrocarbons - observations in the source regions and the tropical tropopause layer, Atmos. Chem. Phys., 12, 1213-1228, doi:10.5194/acp-12-1213-2012, 2012.

Burkholder, J. B., Curtius, J., Ravishankara, A. R., and Lovejoy, E. R.: Laboratory studies of the homogeneous nucleation of iodine oxides, Atmos. Chem. Phys., 4, 19-34, doi:10.5194/acp-419-2004, 2004.

Bussemer, M.: Der Ring-Effekt: Ursachen und Einfluß auf die spektroskopische Messung stratosphärischer Spurenstoffe, Diploma thesis, University of Heidelberg, Heidelberg, Germany, 1993.

Carpenter, L., Fleming, Z., Read, K. A., Lee, J., Moller, S., Hopkins, J., Purvis, R., Lewis, A., Müller, K., Heinold, B., Herrmann, H., Fomba, K. W., van Pinxteren, D., Müller, C., Tegen, I., Wiedensohler, A., Müller, T., Niedermeier, N., Achterberg, E., Patey, M., Kozlova, E., Heimann, M., Heard, D., Plane, J., Mahajan, A., Oetjen, H., Ingham, T., Stone, D., Whalley, L., Evans, M., Pilling, M. J., Leigh, R., Monks, P., Karunaharan, A., Vaughan, S., Arnold, S., Tschritter, J., Pöhler, D., Frieß, U., Holla, R., Mendes, L., Lopez, H., Faria, B., Manning, A., and Wallace, D.: Seasonal characteristics of tropical marine boundary layer air measured at the Cape Verde Atmospheric Observatory, J. Atmos. Chem., 67, 87-140, doi:10.1007/s10874-011-9206-1, 2010.

Carpenter, L. J., MacDonald, S. M., Shaw, M. D., Kumar, R., Saunders, R. W., Parthipan, R., Wilson, J., and Plane, J. M. C.: Atmospheric iodine levels influenced by sea surface emissions of inorganic iodine, Nature Geosci., 6, 108-111, doi:10.1038/ngeo1687, 2013.

Chameides, W. L. and Davis, D. D.: Iodine: Its Possible Role in Tropospheric Photochemistry, J. Geophys. Res., 85, 7383-7398, 1980.

Chance, K. and Spurr, R. J. D.: Ring effect studies; Rayleigh scattering, including molecular parameters for rotational Raman scattering and the Fraunhofer spectrum, Appl. Opt., 36, 5224-5230, 1997.

Clémer, K., Van Roozendael, M., Fayt, C., Hendrick, F., Hermans, C., Pinardi, G., Spurr, R., Wang, P., and De Mazière, M.: Multiple wavelength retrieval of tropospheric aerosol optical properties from MAXDOAS measurements in Beijing, Atmos. Meas. Tech., 3, 863-878, doi:10.5194/amt-3-863-2010, 2010.

Commane, R., Seitz, K., Bale, C. S. E., Bloss, W. J., Buxmann, J., Ingham, T., Platt, U., Pöhler, D., and Heard, D. E.: Iodine monoxide at a clean marine coastal site: observations of high frequency variations and inhomogeneous distributions, Atmos. Chem. Phys., 11, 6721-6733, doi:10.5194/acp-11-6721-2011, 2011.

Deutschmann, T., Beirle, S., Frieß, U., Grzegorski, M., Kern, C., Kritten, L., Platt, U., Prados-Roman, C., Pukite, J., and Wagner, Bodo, T., Werner, K. P.: The Monte Carlo atmospheric radiative transfer model McArtim: Introduction and validation of Jacobians and 3D features, J. Quant. Spectrosc. Ra., 112, 11191137, doi:10.1016/j.jqsrt.2010.12.009, 2011.

Dinter, T.: Modellierung ozeanischer Rückstreuung unter Einbeziehung von Vibrations-Raman-Streuung und die Auswertung anhand von Satellitendaten, Master's thesis, Institute of Environmental Physics, Bremen, 2005.

Finley, B. D. and Saltzman, E. S.: Observations of $\mathrm{Cl}_{2}, \mathrm{Br}_{2}$, and $I_{2}$ in coastal marine air, J. Geophys. Res., 113, D21301, doi:10.1029/2008JD010269, 2008.

Frieß, U., Monks, P., Remedios, J., Rozanov, A., Sinreich, R., Wagner, T., and Platt, U.: MAX-DOAS $\mathrm{O}_{4}$ measurements: A new technique to derive information on atmospheric aerosols: 2. Modeling studies, J. Geophys. Res., 111, D14203, doi:10.1029/2005JD006618, 2006.

Frieß, U., Sihler, H., Sander, R., Pöhler, D., Yilmaz, S., and Platt, U.: The vertical distribution of $\mathrm{BrO}$ and aerosols in the Arctic: Measurements by active and passive differential optical absorption spectroscopy, J. Geophys. Res., 116, D00R04, doi:10.1029/2011JD015938, 2011.

Fueglistaler, S., Dessler, A. E., Dunkerton, T. J., Folkins, I., Fu, Q., and Mote, P. W.: Tropical tropopause layer, Rev. Geophys., 47, RG1004, doi:10.1029/2008RG000267, 2009.

Garland, J. A. and Curtis, H.: Emission of Iodine From the Sea Surface in the Presence of Ozone, J. Geophys. Res., 86, 3183-3186, 1981.

Garland, J. A., Elzerman, A. W., and Penkett, S. A.: The Mechanism for Dry Deposition of Ozone to Seawater Surfaces, J. Geophys. Res., 85, 7488-7492, doi:10.1029/JC085iC12p07488, 1980.

Hayase, S., Yabushita, A., Kawasaki, M., Enami, S., Hoffmann, M. R., and Colussi, A. J.: Heterogeneous Reaction of Gaseous Ozone with Aqueous Iodide in the Presence of Aqueous Organic Species, J. Phys. Chem. A, 114, 6016-6021, 2010.

Hermans, C., Vandaele, A. C., Carleer, M., Fally, S., Colin, R., Jenouvrier, A., Coquart, B., and Mérienne, M.-F.: Absorption Cross-Sections of Atmospheric Constituents: $\mathrm{NO}_{2}, \mathrm{O}_{2}$, and $\mathrm{H}_{2} \mathrm{O}$, Environ. Sci. Pollut. Res., 6, 151-158, 1999.

Hönninger, G., von Friedeburg, C., and Platt, U.: Multi axis differential optical absorption spectroscopy (MAX-DOAS), Atmos. Chem. Phys., 4, 231-254, doi:10.5194/acp-4-231-2004, 2004.

Jammoul, A., Dumas, S., D’Anna, B., and George, C.: Photoinduced oxidation of sea salt halides by aromatic ketones: a source of halogenated radicals, Atmos. Chem. Phys., 9, 4229-4237, doi:10.5194/acp-9-4229-2009, 2009.

Jin, Z., Charlock, T. P., and Rutledge, K.: Analysis of Broadband Solar Radiation and Albedo over the Ocean Surface at COVE, J. Atmos. Oceanic Technol., 19, 1585-1601, 2002.

Jones, C. E., Hornsby, K. E., Sommariva, R., Dunk, R. M., von Glasow, R., McFiggans, G., and Carpenter, L. J.: Quantifying the contribution of marine organic gases to atmospheric iodine, Geophys. Res. Lett., 37, L18804, doi:10.1029/2010GL043990, 2010. 
Kraus, S. G.: DOASIS: A Framework Design for DOAS, Ph.D. thesis, University of Mannheim, 2006.

Krüger, K. and Quack, B.: Introduction to special issue: the TransBrom Sonne expedition in the tropical West Pacific, Atmos. Chem. Phys. Discuss., 12, 1401-1418, doi:10.5194/acpd-121401-2012, 2012.

Krüger, K., Tegtmeier, S., and Rex, M.: Long-term climatology of air mass transport through the Tropical Tropopause Layer (TTL) during NH winter, Atmos. Chem. Phys., 8, 813-823, doi:10.5194/acp-8-813-2008, 2008.

Kurucz, R. L., Furenlid, I., Brault, J., and Testerman, L.: Solar flux atlas from 296 to $1300 \mathrm{~nm}$, Tech. rep., National Solar Observatory, 1984.

Mahajan, A. S., Plane, J. M. C., Oetjen, H., Mendes, L., Saunders, R. W., Saiz-Lopez, A., Jones, C. E., Carpenter, L. J., and McFiggans, G. B.: Measurement and modelling of tropospheric reactive halogen species over the tropical Atlantic Ocean, Atmos. Chem. Phys., 10, 4611-4624, doi:10.5194/acp-10-4611-2010, 2010a.

Mahajan, A. S., Shaw, M., Oetjen, H., Hornsby, K. E., Carpenter, L. J., Kaleschke, L., Tian-Kunze, X., Lee, J. D., Moller, S. J., Edwards, P., Commane, R., Ingham, T., Heard, D. E., and Plane, J. M. C.: Evidence of reactive iodine chemistry in the Arctic boundary layer, J. Geophys. Res., 115, D20303, doi:10.1029/2009JD013665, 2010b.

Mahajan, A. S., Gómez Martín, J. C., Hay, T. D., Royer, S.-J., Yvon-Lewis, S., Liu, Y., Hu, L., Prados-Roman, C., Ordóñez, C., Plane, J. M. C., and Saiz-Lopez, A.: Latitudinal distribution of reactive iodine in the Eastern Pacific and its link to open ocean sources, Atmos. Chem. Phys., 12, 11609-11617, doi:10.5194/acp-12-11609-2012, 2012.

Martino, M., Mills, G. P., Woeltjen, J., and Liss, P. S.: A new source of volatile organoiodine compounds in surface seawater, Geophys. Res. Lett., 36, L01609, doi:10.1029/2008GL036334, 2009.

McFiggans, G.: Atmospheric science: Marine aerosols and iodine emissions, Nature, 433, E13-E13, 2005.

McFiggans, G., Bale, C. S. E., Ball, S. M., Beames, J. M., Bloss, W. J., Carpenter, L. J., Dorsey, J., Dunk, R., Flynn, M. J., Furneaux, K. L., Gallagher, M. W., Heard, D. E., Hollingsworth, A. M., Hornsby, K., Ingham, T., Jones, C. E., Jones, R. L., Kramer, L. J., Langridge, J. M., Leblanc, C., LeCrane, J.-P., Lee, J. D., Leigh, R. J., Longley, I., Mahajan, A. S., Monks, P. S., Oetjen, H., Orr-Ewing, A. J., Plane, J. M. C., Potin, P., Shillings, A. J. L., Thomas, F., von Glasow, R., Wada, R., Whalley, L. K., and Whitehead, J. D.: Iodine-mediated coastal particle formation: an overview of the Reactive Halogens in the Marine Boundary Layer (RHaMBLe) Roscoff coastal study, Atmos. Chem. Phys., 10, 2975-2999, doi:10.5194/acp-10-2975-2010, 2010.

Meller, R. and Moortgat, G.: Temperature dependence of the absorption cross sections of formaldehyde between 223 and 323 $\mathrm{K}$ in the wavelength range $225-375 \mathrm{~nm}$, J. Geophys. Res., 105, 7089-7101, 2000.

Mössinger, J. C., Shallcross, D. E., and Cox, R. A.: UV-VIS absorption cross-sections and atmospheric lifetimes of $\mathrm{CH}_{2} \mathrm{Br}_{2}$, $\mathrm{CH}_{2} \mathrm{I}_{2}$ and $\mathrm{CH}_{2} \mathrm{BrI}$, J. Chem. Soc., Faraday Trans., 94, 13911396, 1998.

Oetjen, H.: Measurements of halogen oxides by scattered sunlight differential optical absorption spectroscopy, Ph.D. thesis, University of Bremen, Germany, 2009.
Peters, C., Pechtl, S., Stutz, J., Hebestreit, K., Hönninger, G., Heumann, K. G., Schwarz, A., Winterlik, J., and Platt, U.: Reactive and organic halogen species in three different European coastal environments, Atmos. Chem. Phys., 5, 3357-3375, doi:10.5194/acp-5-3357-2005, 2005.

Peters, E., Wittrock, F., Großmann, K., Frieß, U., Richter, A., and Burrows, J. P.: Formaldehyde and nitrogen dioxide over the remote western Pacific Ocean: SCIAMACHY and GOME-2 validation using ship-based MAX-DOAS observations, Atmos. Chem. Phys., 12, 11179-11197, doi:10.5194/acp-12-111792012, 2012.

Platt, U. and Hönninger, G.: The Role of Halogen Species in the Troposphere, Chemosphere 52, 325-338, 2003.

Platt, U. and Stutz, J.: Differential Optical Absorption Spectroscopy: Principles and Applications, Physics of Earth and Space Environments, Springer Verlag, 2008.

Puentedura, O., Gil, M., Saiz-Lopez, A., Hay, T., Navarro-Comas, M., Gómez-Pelaez, A., Cuevas, E., Iglesias, J., and Gomez, L.: Iodine monoxide in the north subtropical free troposphere, Atmos. Chem. Phys., 12, 4909-4921, doi:10.5194/acp-12-49092012, 2012.

Quack, B., Atlas, E., Krüger, K., Taylor, B., Dinter, T., Bracher, A., Petrick, G., Stange, K., Fuhlbrügge, S., Tegtmeier, S., Wache, S., and Wallace, D.: Distribution and air-sea fluxes of halocarbons through the Western Pacific, in preparation, 2013.

Rattigan, O. V., Shallcross, D. E., and Cox, R. A.: UV absorption cross-sections and atmospheric photolysis rates of $\mathrm{CF}_{3} \mathrm{I}, \mathrm{CH}_{3} \mathrm{I}$, $\mathrm{C}_{2} \mathrm{H}_{5} \mathrm{I}$ and $\mathrm{CH}_{2} \mathrm{ICl}$, J. Chem. Soc., Faraday Trans., 93, 28392846, 1997.

Read, K. A., Mahajan, A. S., Carpenter, L. J., Evans, M. J., Faria, B. V. E., Heard, D. E., Hopkins, J. R., Lee, J. D., Moller, S. J., Lewis, A. C., Mendes, L., McQuaid, J. B., Oetjen, H., Saiz-Lopez, A., Pilling, M. J., and Plane, J. M. C.: Extensive halogen-mediated ozone destruction over the tropical Atlantic Ocean., Nature, 453, 1232-1235, doi:10.1038/nature07035, 2008.

Reeser, D. I., George, C., and Donaldson, D. J.: Photooxidation of Halides by Chlorophyll at the Air-Salt Water Interface, J. Phys. Chem. A, 113, 8591-8595, 2009.

Ridder, T., Gerbig, C., Notholt, J., Rex, M., Schrems, O., Warneke, T., and Zhang, L.: Ship-borne FTIR measurements of $\mathrm{CO}$ and $\mathrm{O}_{3}$ in the Western Pacific from $43^{\circ} \mathrm{N}$ to $35^{\circ} \mathrm{S}$ : an evaluation of the sources, Atmos. Chem. Phys., 12, 815-828, doi:10.5194/acp-12815-2012, 2012.

Rodgers, C. and Connor, B.: Intercomparison of remote sounding instruments, J. Geophys. Res, 108, 4116-4229, doi:10.1029/2002JD002299, 2003.

Rodgers, C. D.: Inverse methods for atmospheric sounding, theory and practice, Series on Atmospheric, Oceanic and Planetary Physics, World Scientific, 2000.

Roscoe, H. K., Van Roozendael, M., Fayt, C., du Piesanie, A., Abuhassan, N., Adams, C., Akrami, M., Cede, A., Chong, J., Clémer, K., Friess, U., Gil Ojeda, M., Goutail, F., Graves, R., Griesfeller, A., Grossmann, K., Hemerijckx, G., Hendrick, F., Herman, J., Hermans, C., Irie, H., Johnston, P. V., Kanaya, Y., Kreher, K., Leigh, R., Merlaud, A., Mount, G. H., Navarro, M., Oetjen, H., Pazmino, A., Perez-Camacho, M., Peters, E., Pinardi, G., Puentedura, O., Richter, A., Schönhardt, A., Shaiganfar, R., Spinei, E., Strong, K., Takashima, H., Vlemmix, T., Vrekoussis, M., Wagner, T., Wittrock, F., Yela, M., Yilmaz, S., Boersma, F. 
Hains, J., Kroon, M., Piters, A., and Kim, Y. J.: Intercomparison of slant column measurements of $\mathrm{NO}_{2}$ and $\mathrm{O}_{4}$ by MAX-DOAS and zenith-sky UV and visible spectrometers, Atmos. Meas. Tech., 3, 1629-1646, doi:10.5194/amt-3-1629-2010, 2010.

Rothman, L., Gordon, I., Barbe, A., Benner, D., Bernath, P., Birk, M., Boudon, V., Brown, L., Campargue, A., Champion, J.-P., Chance, K., Coudert, L., Dana, V., Devi, V., Fally, S., Flaud, J.-M., Gamache, R., Goldman, A., Jacquemart, D., Kleiner, I., Lacome, N., Lafferty, W., Mandin, J.-Y., Massie, S., Mikhailenko, S., Miller, C., Moazzen-Ahmadi, N., Naumenko, O., Nikitin, A., Orphal, J., Perevalov, V., Perrin, A., PredoiCross, A., Rinsland, C., Rotger, M., Simecková, M., Smith, M., Sung, K., Tashkun, S., Tennyson, J., Toth, R., Vandaele, A., and Auwera, J. V.: The HITRAN 2008 molecular spectroscopic database, J. Quant. Spectrosc. Ra. Transfer, 110, 533-572, doi:10.1016/j.jqsrt.2009.02.013, 2009.

Rozanov, A., Bovensmann, H., Bracher, A., Hrechanyy, S., Rozanov, V., Sinnhuber, M., Stroh, F., and Burrows, J.: $\mathrm{NO}_{2}$ and $\mathrm{BrO}$ vertical profile retrieval from SCIAMACHY limb measurements: Sensitivity studies, Adv. Space Res., 36, 846-854, doi:10.1016/j.asr.2005.03.013, 2005.

Saiz-Lopez, A. and Plane, J. M. C.: Novel iodine chemistry in the marine boundary layer, Geophys. Res. Lett., 31, L04112, doi:10.1029/2003GL019215, 2004.

Saiz-Lopez, A., Shillito, J. A., Coe, H., and Plane, J. M. C.: Measurements and modelling of $\mathrm{I}_{2}, \mathrm{IO}, \mathrm{OIO}, \mathrm{BrO}$ and $\mathrm{NO}_{3}$ in the mid-latitude marine boundary layer, Atmos. Chem. Phys., 6, 1513-1528, doi:10.5194/acp-6-1513-2006, 2006.

Saiz-Lopez, A., Mahajan, A., Salmon, R., Bauguitte, S., Jones, A., Roscoe, H., and Plane, J.: Boundary layer halogens in coastal Antarctica, Science, 317, 348-351, 2007.

Saiz-Lopez, A., Plane, J. M. C., Baker, A. R., Carpenter, L. J., von Glasow, R., Gómez Martín, J. C., McFiggans, G., and Saunders, R. W.: Atmospheric Chemistry of Iodine, Chem. Rev., 112, 1773-1804, doi:10.1021/cr200029u, 2012.

Schönhardt, A., Richter, A., Wittrock, F., Kirk, H., Oetjen, H., Roscoe, H. K., and Burrows, J. P.: Observations of iodine monoxide columns from satellite, Atmos. Chem. Phys., 8, 637-653, doi:10.5194/acp-8-637-2008, 2008.

Schönhardt, A., Begoin, M., Richter, A., Wittrock, F., Kaleschke, L., Gómez Martín, J. C., and Burrows, J. P.: Simultaneous satellite observations of IO and BrO over Antarctica, Atmos. Chem. Phys., 12, 6565-6580, doi:10.5194/acp-12-6565-2012, 2012.

Seitz, K., Buxmann, J., Pöhler, D., Sommer, T., Tschritter, J., Neary, T., O'Dowd, C., and Platt, U.: The spatial distribution of the reactive iodine species IO from simultaneous active and passive DOAS observations, Atmos. Chem. Phys., 10, 2117-2128, doi:10.5194/acp-10-2117-2010, 2010.

Sinreich, R., Frieß U., and Platt, U.: Multi axis differential optical absorption spectroscopy (MAX-DOAS) of gas and aerosol distributions, Faraday Discuss., 130, 153-164, doi:10.1039/b419274p, 2005.

Solomon, S., Garcia, R. R., and Ravishankara, A. R.: On the role of iodine in ozone depletion, J. Geophys. Res., 99, 20491-20499, doi:10.1029/94JD02028, 1994.
Sommariva, R. and von Glasow, R.: Multi-phase halogen chemistry in the tropical Atlantic Ocean, Environ. Sci. Technol., 46, 1042910437, doi:10.1021/es300209f, 2012.

Sommariva, R., Bloss, W., and von Glasow, R.: Uncertainties in gasphase atmospheric iodine chemistry, Atmos. Environ., 57, 219232, 2012.

Spietz, P., Martin, J., and Burrows, J. P.: Spectroscopic studies of the I2/O3 photochemistry. Part 2. Improved spectra of iodine oxides and analysis of the IO absorption spectrum, J. Photochem. Photobiol. A: Chem., 176, 50-67, 2005.

Van Roozendael, M. and Fayt, C.: WinDOAS 2.1. Software User Manual, IASB/BIRA Uccle, Belgium, 2001.

Vandaele, A. C., Hermans, C., Simon, P. C., Carleer, M., Colin, R., Fally, S., Mérienne, M. F., Jenouvrier, A., and Coquart, B.: Measurements of the $\mathrm{NO}_{2}$ absorption cross-section from 42,000 $\mathrm{cm}^{-1}$ to $10,000 \mathrm{~cm}^{-1}(2380-1000 \mathrm{~nm})$ at $220 \mathrm{~K}$ and 294 K., J. Quant. Spectrosc. Ra., 59, 171-184, doi:10.1016/S00224073(97)00168-4, 1998.

Vogt, R., Sander, R., von Glasow, R., and Crutzen, P. J.: Iodine Chemistry and its Role in Halogen Activation and Ozone Loss in the Marine Boundary Layer: A Model Study, J. Atmos. Chem., 32, 375-395, doi:10.1023/A:1006179901037, 1999.

Volkamer, R., Spietz, P., Burrows, J. P., and Platt, U.: Highresolution absorption cross-section of Glyoxal in the UV/vis and IR spectral ranges, J. Photoch. Photobio. A: Chemistry, 172, 3546, 2005.

von Glasow, R., Sander, R., Bott, A., and Crutzen, P. J.: Modeling halogen chemistry in the marine boundary layer 1 . Cloud-free MBL, J. Geophys. Res., 107, 4341, doi:10.1029/2001JD000942, 2002.

Vountas, M., Richter, A., Wittrock, F., and Burrows, J. P.: Inelastic scattering in ocean water and its impact on trace gas retrievals from satellite data, Atmos. Chem. Phys., 3, 1365-1375, doi:10.5194/acp-3-1365-2003, 2003.

Wagner, T., Dix, B., von Friedeburg, C., Frieß, U., Sanghavi, S., Sinreich, R., and Platt, U.: MAX-DOAS $\mathrm{O}_{4}$ measurements: A new technique to derive information on atmospheric aerosols - principles and information content, J. Geophys. Res., 109, D22205, doi:10.1029/2004JD004904, 2004.

Wilmouth, D. M., Hanisco, T. F., Donahue, N. M., and Anderson, J. G.: Fourier transform ultraviolet spectroscopy of the $A^{2} \Pi_{3 / 2} \leftarrow X^{2} \Pi_{3 / 2}$ transition of BrO, J. Phys. Chem. A, 103, 8935-8945, doi:10.1021/jp991651o, 1999.

Wittrock, F., Oetjen, H., Richter, A., Fietkau, S., Medeke, T., Rozanov, A., and Burrows, J. P.: MAX-DOAS measurements of atmospheric trace gases in Ny-Ålesund - Radiative transfer studies and their application, Atmos. Chem. Phys., 4, 955-966, doi:10.5194/acp-4-955-2004, 2004.

Zindler, C., Bracher, A., Marandino, C. A., Taylor, B., Torrecilla, E., Kock, A., and Bange, H. W.: Sulphur compounds, methane, and phytoplankton: interactions along a north-south transit in the western Pacific Ocean, Biogeosciences Discuss., 9, 1501115049, doi:10.5194/bgd-9-15011-2012, 2012. 